Original paper

\title{
Metabasic rocks in the Varied Group of the Moldanubian Zone, southern Bohemia - their petrology, geochemical character and possible petrogenesis
}

\author{
Vojtěch JANOUŠEK ${ }^{1,2 *}$, Stanislav VRÁNA ${ }^{1}$, Vojtěch ERBAN ${ }^{1}, K^{\prime}$ Karel VOKURKA ${ }^{1 \dagger}$, \\ Milan DRÁBEK'
}

${ }^{1}$ Czech Geological Survey, Klárov 3, 11821 Prague 1, Czech Republic; vojtech.janousek@geology.cz

${ }^{2}$ Institute of Petrology and Structural Geology, Charles University, Albertov 6, 12843 Prague 2, Czech Republic

* Corresponding author

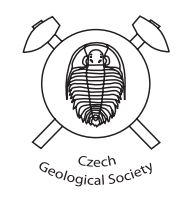

Metabasic rocks form an important constituent of the Chýnov and Český Krumlov units belonging to the Varied Group (Moldanubian Zone, south Bohemia). The amphibolites are dominated by amphibolite-facies mineral assemblages of mainly tschermakitic amphibole and plagioclase. Hornblendes show compositional variation with $\mathrm{Si} \sim 6.5 \mathrm{apfu}, \mathrm{Mg} /(\mathrm{Mg}$ $+\mathrm{Fe}) \sim 0.5$ and $(\mathrm{Na}+\mathrm{K})_{\mathrm{A}} \sim 0.5$ apfu. Garnet with clinopyroxene are subordinate and occur in a few samples only. No relics of previous greenschist- or granulite-facies assemblages have been observed, most likely due to the relatively simple metamorphic history.

The petrology indicates rather close correlation of the Chýnov and Český Krumlov units. The similarities include presence of dolomite in carbonate bodies, graphite schists, rocks with marialitic scapolite, locally also Ti-andradite ( \pm magnetite, epidote) oxidic assemblages and thin layers of Mn-rich garnet-quartz rocks. However, there is a major difference in the oxidation state. Most Chýnov amphibolites have $\mathrm{Fe}_{2} \mathrm{O}_{3} / \mathrm{FeO}=0.70-1.00$ and their protolith probably experienced an early incipient oxidation. Great deal of the parental basalts thus could have been effusive. The Český Krumlov amphibolites have $\mathrm{Fe}_{2} \mathrm{O}_{3} / \mathrm{FeO} \leq 0.4$, perhaps because they show much closer association with graphite schists that could have been responsible for the reduction of the adjacent rock units.

The dataset is dominated by EMORB-like tholeiite basalts interpreted as having been derived by Early Palaeozoic melting of a strongly depleted mantle source $\left(\varepsilon_{N d}^{500}=+8.6\right.$ to $\left.+9.4 ; \mathrm{T}_{N d}^{D M}=0.43-0.50 \mathrm{Ga}\right)$. This argues stoutly against Precambrian age of the Varied Group in south Bohemia. The composition of the remaining samples reflects contamination by upper continental crust $\left(\varepsilon_{N d}^{500}=+3.1\right.$ to +1.3 , progressive enrichment in $\mathrm{Th}$, development of a significant negative $\mathrm{Nb}$, and lesser $\mathrm{P}$ and Ti anomalies on the NMORB-normalized spiderplots).

A much smaller group of amphibolites is characterised by steep REE patterns $\left(\mathrm{La}_{\mathrm{N}} / \mathrm{Yb}_{\mathrm{N}}=5.5-11\right)$ and high contents of $\operatorname{HFSE}(\mathrm{Nb}, \mathrm{Ta}, \mathrm{Zr}$ and $\mathrm{P})$. It is of a clear OIB affinity, with parental alkali basalt $(\mathrm{Nb} / \mathrm{Y}=0.7-1.6)$ generated by a low degree of partial melting of a deep, garnet-bearing asthenospheric mantle source $\left(\varepsilon_{N d}^{500}=+4.5\right.$ to $+6.1 ; \mathrm{T}_{N d}^{D M}=0.75-0.83$ $\mathrm{Ga})$.

Metamorphosed doleritic/gabbroic dykes cutting the Palaeoproterozoic Světlík orthogneiss show rather unradiogenic Nd isotopic composition $\left(\varepsilon_{N d}^{500}=+0.1\right.$ and $-3.6 ; \mathrm{T}_{N d}^{D M}=1.34$ and $\left.2.03 \mathrm{Ga}\right)$. This precludes closed-system crystallization from depleted mantle derived melts in Phanerozoic times. The exact age and nature of their parental magma remain enigmatic but any genetic link with the amphibolites in the structurally overlying Český Krumlov Varied Unit seems ruled out. Overall, the most likely tectonic setting of the magmatism was attenuated lithosphere, subjected to an Early Palaeozoic extension, leading eventually to fragmentation of the northern Gondwana margin. The minor OIB component preserved as alkali basalts as well as some contribution to the EMOR-like basaltic magmas was probably added by a rising mantle plume.

Keywords: amphibolites, petrology, whole-rock geochemistry, Nd isotopes, Moldanubian Zone, Bohemian Massif

Received: 18 January 2008; accepted 19 March 2008; handling editor: V. Kachlik

\section{Introduction}

Constraining the age and petrogenesis of dismembered and metamorphosed pre-Variscan volcanosedimentary complexes represents one of real challenges in collisional orogens, with the European Variscan chain being no exception. As the reconstruction of the primary fabrics, structures, petrography and mineralogy of the original volcanosedimentary sequences is often difficult, if not impossible, an alternative approach has to be sought. Whole-rock geochemical as well as $\mathrm{Sr}-\mathrm{Nd}$ isotopic compositions of the volcanic rocks - and basic ones in particular - are sensitive indicators of the source composition and consequently also of the geotectonic setting (e.g., Wilson 1989 and references therein). 
Fortunately many petrogenetically significant trace elements are relatively immobile during alteration and metamorphism. Especially those with intermediate ionic potential (such as HFSE and REE) can provide useful information even in rocks subjected to a high-grade (up to upper amphibolite-facies) metamorphic overprint (Floyd and Winchester 1975, 1978; Winchester and Floyd 1976, 1977; Wood et al. 1979; Wood 1980; Pearce 1996). Similarly the Nd isotopic system is rather resistant to metamorphic resetting, unless $\mathrm{CO}_{2}$-rich fluids are involved (DePaolo 1988; Dickin 1995; Faure 2001). The radiogenic isotopic ratios do not change during closedsystem fractional crystallization, and should thus still reflect the source composition. Alternatively, the radiogenic isotopes are capable of providing vital constraints on the extent and mechanism of open-system interactions affecting compositions of the basic parental magmas, for instance crustal assimilation, which is usually coupled with fractional crystallization (DePaolo 1981).

Taken together, careful petrologic, whole-rock geochemical and $\mathrm{Nd}$ isotopic studies of metabasic rocks, and metabasalts in particular, seem a promising line of research that should contribute to our better understanding of the primary evolution and geotectonic environment of the volcanosedimentary sequences. The Variscides are a typical example of a collisional orogen, in which the original information on field relations, palaeogeographic configuration and geotectonic position of individual older volcanic suites has been, largely or completely, wiped out by the intense tectonometamorphic reworking. Indeed, the combined petrologic, geochemical and isotopic approach has been successfully applied to several rock complexes in the Bohemian Massif, which forms a key Central European part of the Variscan chain. It yielded invaluable information concerning their character, classification, age, genesis and tectonic significance (e.g., Patočka 1987; Winchester et al. 1998; Floyd et al. 1996, 2000; 2002).

Metabasites represent an important constituent of the Moldanubian Zone, which is considered to be the orogenic root of the Variscan orogen in Bohemian Massif (Schulmann et al. 2005, 2008). They are abundant, associated with prevalent gneisses and subordinate carbonate rocks, in the amphibolite-facies Varied Group, particularly at the contact with the HP-HT Gföhl Unit. Modern studies utilizing whole-rock geochemical data from the Moldanubian metabasic rocks are still regrettably scarce (Matějovská 1987; Patočka 1991; Finger and Steyrer 1995; Fritz 1995; Kachlík 1999; Mayer et al. 2005) and their $\mathrm{Nd}$ isotopic compositions remain nearly unconstrained (but cf. Mayer et al. 2007).

Given the high-grade metamorphism of the Varied Group (mainly second sillimanite isograd), polyphase deformation history, and the superimposed effects of later Variscan contact metamorphism, it is difficult to reconstruct primary features of the original basaltic rocks. In this contribution we present new data for metabasic rocks from two prominent and interesting segments of the pre-Variscan volcanosedimentary crust of the Varied Group, the Chýnov and Český Krumlov units in southern Bohemia (Fig. 1). The most interesting finding is that they contain Early Palaeozoic tholeiitic and subordinate alkaline metabasalts, providing more evidence for the probable Early Palaeozoic age for the Varied Group in southern Bohemia and the mechanism of the fragmentation of the Gondwana margin in general.

\section{Geological setting}

\subsection{Subdivision of the Moldanubian Zone}

The Moldanubian Zone (MZ) in the Bohemian Massif is a heterogeneous crustal (and upper mantle) stack of several major allochthonous units or terranes, assembled during the Variscan orogeny and modified by several superimposed deformation and metamorphic recrystallization events. In southern Bohemia, these units are termed traditionally the Monotonous, Varied and Gföhl groups or units (Fiala et al. 1995) (Fig. 1). Moreover, displaced segments of older basement are incorporated in the structure of the MZ, including the Palaeoproterozoic Světlík orthogneiss in southern Bohemia (Wendt et al. 1993; Fiala et al. 1995) and the Mesoproterozoic Dobra gneiss in Lower Austria (Gebauer and Friedl 1994; Friedl et al. 2004).

\subsubsection{Gföhl Unit}

The high-grade Gföhl Unit, with its typical occurrence in Lower Austria, contains mainly nebulitic biotite migmatites, bodies of felsic granulites and minor pyroxene granulites accompanied by pyrope peridotites, garnet clinopyroxenites, eclogites, amphibolites and minor paragneisses/migmatites. A comparable assemblage of rock types occurs in several parts of the MZ, including southern Bohemia (Fig. 1).

As summarised by Janoušek et al. (2004), the protoliths to Gföhl gneisses/migmatites and felsic granulites seem predominantly Ordovician to Devonian in age (c. 470-430, 400 and $360 \mathrm{Ma}$ : Wendt et al. 1994; Kröner et al. 2000; Friedl et al. 2004). The granulitic rocks of the Gföhl Unit equilibrated at high pressures, corresponding to eclogite-facies conditions (O'Brien and Rötzler 2003; O'Brien 2006, 2008), and were assembled and tectonically emplaced to higher crustal levels at around $340 \mathrm{Ma}$ (Kröner et al. 2000 and references therein). The 

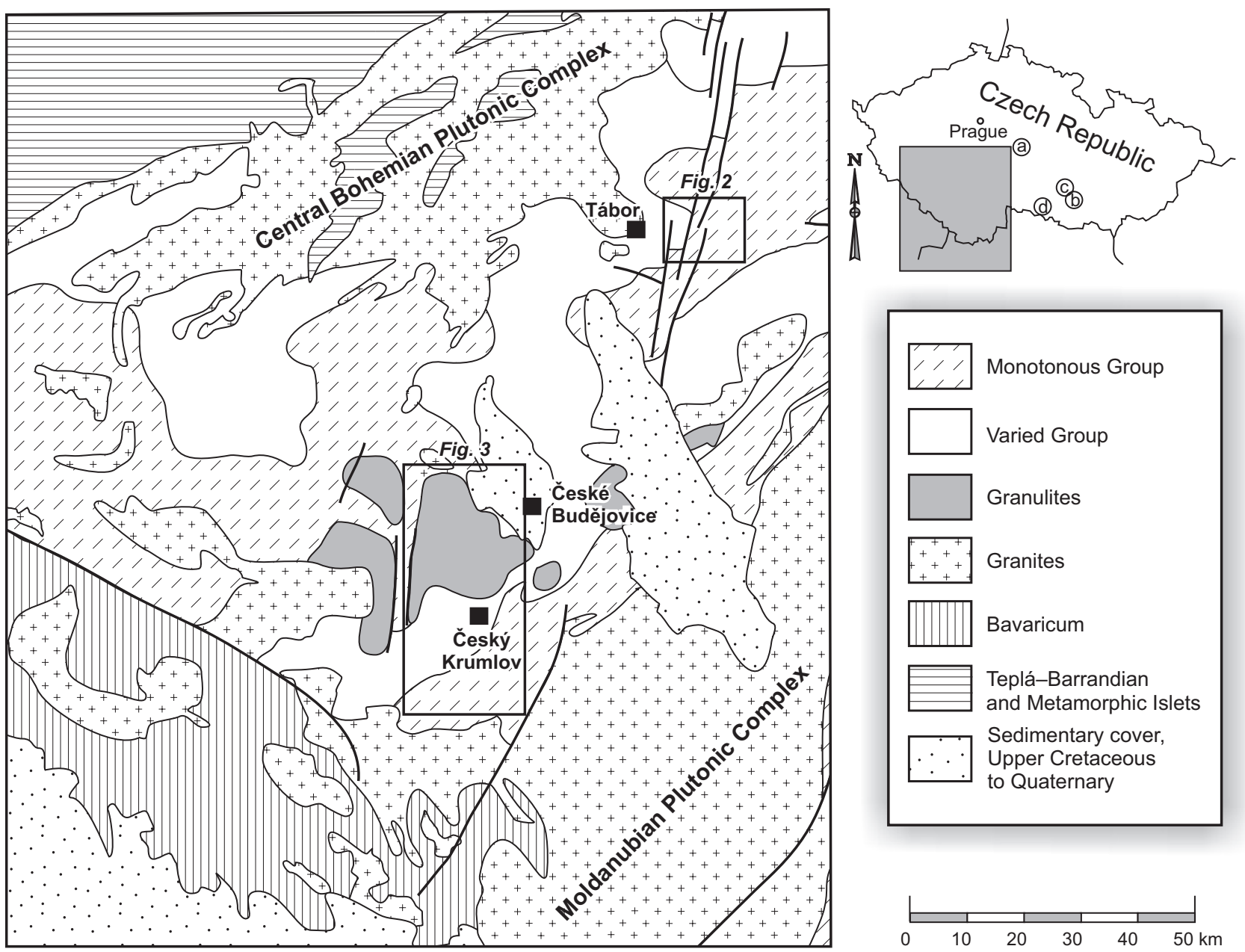

Fig. 1 Geological sketch of the southern Bohemia showing the regional context the studied metabasic occurrences (simplified from Fiala et al. 1995). The rectangles refer to the location of more detailed maps for the Chýnov and Český Krumlov areas within the Moldanubian Zone (Figs 2 and 3). Inset: position of the main map area in the Czech Republic. Labelled are also other localities mentioned in the text: (a) - Rataje Zone, (b) - Moravský Krumlov, (c) - Náměšt', (d) - Jemnice.

nappe structures in southern Bohemia, if ever present, were strongly modified by later deformation (Rajlich et al. 1986; Vrána and Šrámek 1999; Franěk et al. 2006) and this may be so even for the classic Austrian terrain (Racek et al. 2006).

\subsubsection{Monotonous Group}

The Monotonous Group mainly consists of biotite-sillimanite paragneisses ( \pm cordierite), which are partly migmatitic and contain intercalations of orthogneisses, quartzites and minor amphibolites. Eclogites are scarce. Rare direct $\mathrm{U}-\mathrm{Pb}$ geochronological evidence indicates a likely Neoproterozoic age $(<727 \pm 106 \mathrm{Ma})$ for the metasedimentary sequence of the Monotonous Group in the Kaplice area (Kröner et al. 1988). The Variscan amphibolite-facies metamorphism has been dated conventionally by the same authors at $367_{-20}^{+18} \mathrm{Ma}$.

\subsubsection{Varied Group}

Both the Varied and Monotonous groups contain biotite paragneisses and migmatites as the dominant lithology. However, the Varied Group is characterised by the presence of numerous intercalations of marble ( \pm dolomite), amphibolite, calc-silicate gneiss, graphitic gneiss and quartzite. The characteristics of the Varied Group in various parts of the MZ indicate that all the occurrences are probably not coherent and may in part reflect differences in age (see e.g. Finger et al. 2007 for a review). Hence, it may be appropriate to designate individualized areas of the Varied Group as separate units. 


\subsection{Moldanubian amphibolites}

\subsubsection{Amphibolite occurrences in the Mol- danubian Zone}

Amphibolite occurrences are scattered throughout the Varied Group of the MZ both in the Czech Republic and adjacent areas of Lower Austria, especially in the socalled Raabs Unit, sandwiched along the contact between the Varied Group and the Gföhl Unit (Finger and Steyrer 1995; Fritz 1995; Mayer et al. 2005, 2007).

Metabasites in the Bohemian part of the Moldanubian Zone form small, elongated bodies, typically concordant with the fabrics in the adjacent metasedimentary rocks. Their most abundant occurrences are in the Rataje Zone in the Sázava valley, in the Varied Group around Chýnov and Český Krumlov, in the region between Náměšt' and Moravský Krumlov and around Jemnice (see Moravcová 1999, fig. 1, for a synoptical map). The amphibolites consist of mainly tschermakitic amphibole and plagioclase (andesine-labradorite); types with garnet and relict clinopyroxene are comparably rare (Němec 1995).

\subsubsection{Previous geochemical studies}

In W Moravia, amphibolite bodies encircle the Náměšt' granulite Massif (Šichtářová 1981; Němec 1996a). Matějovská (1987) studied the chemistry of amphibolites in SW Moravia, in a belt extending from Slavonice by the Austrian border to the occurrences within the Náměšt' granulite Massif. The various types of amphibolites in the Strážek Unit NE of the Třebíč durbachite pluton were the subject of detailed reports by Němec $(1994,1995$, 1996b, 1997). Metamorphic changes to the whole-rock geochemical signatures of the Moldanubian amphibolites were investigated by Němec (1999).

The work of Kachlík (1999) dealt with the structural geology, petrology, mineral and whole-rock geochemistry of rock complexes in the so-called Rataje Zone, i.e. at the contact between the Varied Group, Kutná Hora Crystalline Unit and Central Bohemian Plutonic Complex/Bohemicum. He concluded that the geochemical signature of amphibolites from the Šternberk-Čáslav Unit resembles that of the amphibolites in Varied Group of southern Bohemia.

Patočka (1991) concentrated on the geochemistry of the various amphibolite types from around Český Krumlov. The whole-rock geochemistry of the Chýnov area near Tábor was described in short, preliminary reports by Janoušek et al. (1997) and René (2007). A more detailed contribution by Němec (1998) dealt with Mg-rich amphibolites, interpreted as metamorphosed Ol- and Cpx-rich cumulates.

\section{Analytical techniques}

\subsection{Electron microprobe}

Mineral analyses were carried out with the CamScan 3400 electron microscope using energy dispersion analyser Link ISIS at the Czech Geological Survey, PragueBarrandov (CGS). Analytical conditions were $2.5 \mathrm{nA}$, $15 \mathrm{kV}, 60 \mathrm{~s}$ counting time on sample, $120 \mathrm{~s}$ on standard (J. Malec, analyst). Mineral formulae were recalculated using the R language package GCDkit-Mineral (Janoušek et al. 2006a).

\subsection{Whole-rock geochemistry}

Most of the major-element whole-rock analyses were performed by wet chemical methods in the laboratories of the Czech Geological Survey, Prague-Barrandov. The trace elements were analysed in the ACME Analytical Laboratories, Vancouver, Canada. Most were determined by $\mathrm{LiBO}_{2} / \mathrm{Li}_{2} \mathrm{~B}_{4} \mathrm{O}_{7}$ fusion and ICP-MS/ES, except for precious and base metals determined by aqua regia digestion followed by ICP-MS. Data management, recalculation, plotting and statistical evaluation of the data were facilitated using the R language package GCDkit (Janoušek et al. 2006b).

\subsection{Radiogenic isotopes ( $\mathrm{Sr}$ and $\mathrm{Nd}$ )}

For the isotopic study, samples were dissolved using a combined $\mathrm{HF}-\mathrm{HCl}-\mathrm{HNO}_{3}$ attack. Strontium and bulk REE of the Chýnov set were isolated by standard cationexchange chromatography techniques on quartz columns with BioRad AG50Wx8 resin. Nd was further separated on quartz columns with Biobeads S-X8 coated with HDEHP (Richard et al. 1976). The Rb and Sr concentrations, and the $\mathrm{Rb} / \mathrm{Sr}$ ratios, were determined using XRF apparatus in the CGS by an approach similar to Harvey and Atkin (1981 and references therein). The Sm and $\mathrm{Nd}$ concentrations were obtained by isotope dilution using ${ }^{149} \mathrm{Sm}$ and ${ }^{148} \mathrm{Nd}$ spikes (Richard et al. 1976; Vokurka 1995).

Strontium of the Český Krumlov set was isolated by exchange chromatography techniques on PP columns with Sr.spec Eichrom resin and bulk REE on PP columns filled with TRU.spec Eichrom resin (Pin et al. 1994). The $\mathrm{Nd}$ was further separated on PP columns with Ln.spec Eichrom resin (Pin and Zalduegui 1997). Further analytical details were recently reported by Míková and Denková (2007). The Rb, Sr, Sm and Nd concentrations were obtained by ICP-MS in Acme Analytical Laboratories, Canada, as given above. 

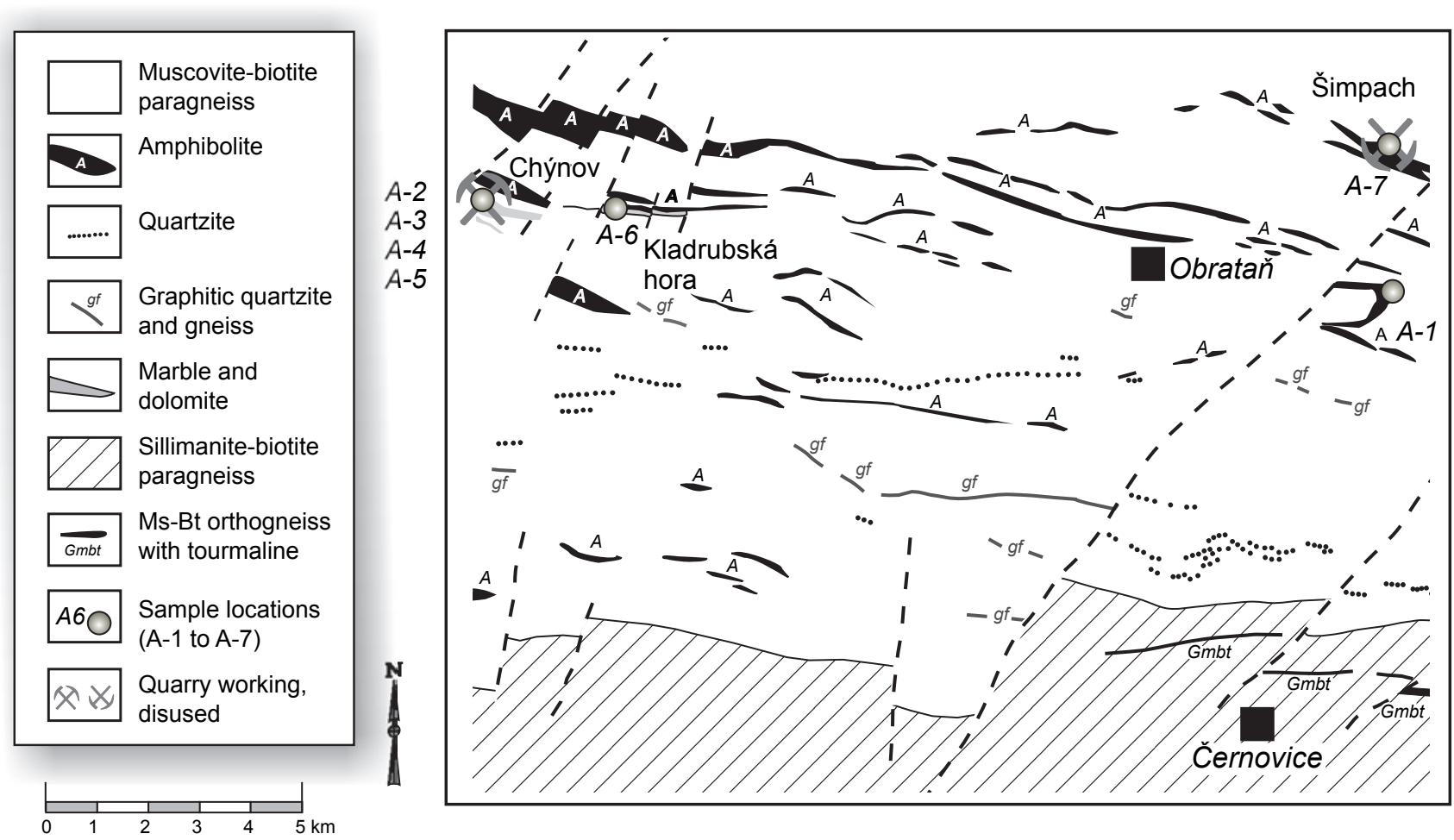

Fig. 2 Sample location and geology of the Chýnov area. Simplified from Czech Geological Survey map 1: 25000.

For both datasets, isotopic analyses were performed on a Finnigan MAT 262 thermal ionization mass spectrometer in static mode using a double Re filament assembly (CGS). The ${ }^{143} \mathrm{Nd} /{ }^{144} \mathrm{Nd}$ ratios were corrected for mass fractionation to ${ }^{146} \mathrm{Nd} /{ }^{144} \mathrm{Nd}=0.7219,{ }^{87} \mathrm{Sr} /{ }^{86} \mathrm{Sr}$ ratios assuming ${ }^{86} \mathrm{Sr}{ }^{88} \mathrm{Sr}=0.1194$. External reproducibility for the Chýnov samples is given by results of repeat analyses of the La Jolla $\left({ }^{143} \mathrm{Nd} /{ }^{144} \mathrm{Nd}=0.511858 \pm 26(2 \sigma), \mathrm{n}=18\right)$ and the NBS $987\left({ }^{87} \mathrm{Sr} r{ }^{86} \mathrm{Sr}=0.710250 \pm 24(2 \sigma), \mathrm{n}=10\right)$ isotopic standards. For the Český Krumlov series, the repeat analyses of the La Jolla standard yielded ${ }^{143} \mathrm{Nd} /{ }^{144} \mathrm{Nd}$ $=0.511851 \pm 14(2 \sigma, \mathrm{n}=24)$.

The decay constants applied to age-correct the isotopic ratios are from Steiger and Jäger $(1977$ - Sr) and Lugmair and Marti $(1978-\mathrm{Nd})$. The $\varepsilon_{N d}^{i}$ values and single-stage CHUR Nd model ages were obtained using Bulk Earth parameters of Jacobsen and Wasserburg (1980), the single-stage Depleted Mantle Nd model ages $\left(\mathrm{T}_{N d}^{D M}\right)$ were calculated after Liew and Hofmann (1988).

\section{Field relations for the studied samples}

The relations of the Varied Unit in the Chýnov and Český Krumlov areas probably indicate rather close lithological correlations. Analogies include the presence of dolomite in the carbonate bodies, association with graphite schists, presence of schists with marialitic scapolite, occurrence of localized Ti-andradite ( \pm magnetite, epidote) assemblages, and thin layers of Mn-rich garnet-quartz rocks including Mn-rich garnetiferous gneisses. Recurrence of such unusual rock types is an important link in comparing the two units.

\subsection{Chýnov Varied Unit}

Amphibolites in the Chýnov area represent an interesting subject for a study for several reasons:

(a) The region between Chýnov and Obrataň (Fig. 2) is characterised by a relatively simple tectonic structure, and in particular the preservation of relatively old fabrics (most likely ? $\left.\mathrm{D}_{1}\right)$, with the main foliation and varied intercalations trending WNW-ESE. This means that the Chýnov region was unaffected by younger deformation and recrystallization events that obscured the situation in many places in the Moldanubian Zone.

(b) Apart form amphibolites the local sequence of the Varied Group also includes marbles (dolomites), quartzites and graphite-bearing rocks (Fig. 2), facilitating lithological correlations. 
(c) Its position is distant from regions affected by migmatitization and contact metamorphism caused by the Moldanubian (South Bohemian) Plutonic Complex.

(d) There is a surprising dearth of detailed geochemical studies from these rocks.

Amphibolites in the broader environs of Chýnov village were sampled at several locations (Fig. 2).

A-1 outcrop $2.7 \mathrm{~km}$ ESE of Obrataň, $15 \mathrm{~km}$ east of Chýnov, 49²5'23.33" N; 14'58'8.79" E

This sample comes from a several metres thick layer of amphibolite surrounded by biotite paragneiss. The rock is homogeneous, fine-grained and exhibits distinct foliation and lineation.

A-2 to A-5 working quarry at Pacovská hora Hill, $2.2 \mathrm{~km}$ NNE of Chýnov, 49²5'47.89'N; 14'49'49.53" E

Samples A-2 to A-5 were collected in large, then (1995) working quarry on the western slopes of the Pacovská hora hill. The quarry exposed crystalline limestones, calc-silicate gneisses, amphibolites and muscovitebiotite paragneisses \pm sillimanite. Amphibolites form conformable layers several metres up to tens of metres thick, interbanded with calcite- and dolomite-calcite marble or paragneiss. Due to a strong metamorphic overprint and high rates of deformation, it is difficult to decide whether they originally represented sills, lava flows or tuff horizons. Rather high oxidation state indicates syn-sedimentary lavas deposited in a shallow sea, with possible episodes of subaeric exposure, as the prevailing protolith.

A-6 disused quarry at the Kladrubská hora hill, $3.6 \mathrm{~km}$ NE of Chýnov, 49²5'49.37" N; 14\%51'11.93" E

Sample is a fine-grained, strongly foliated rock with widely scattered mineral aggregates $1-2 \mathrm{~mm}$ across, rich in plagioclase.

A-7 disused quarry in forest $0.8 \mathrm{~km}$ SE of Šimpach, $49^{\circ} 26^{\prime} 5.91^{\prime \prime} \mathrm{N} ; 14^{\circ} 59^{\prime} 7.37^{\prime \prime} \mathrm{E}$

Amphibolite A-7 is a fine-grained, foliated rock with plagioclase-rich aggregates $(1-3 \mathrm{~mm})$, which are somewhat streaky and stretched parallel to the foliation. The amphibolite body at Šimpach is intimately associated with Mg-rich clinopyroxenite.

\subsection{Amphibolites and metadolerites/meta- gabbros in the Český Krumlov area}

Five samples of amphibolites from the surroundings of the town of Český Krumlov and three samples of metadolerites/metagabbros from the Světlík and Kovářov areas (Fig. 3) were obtained for comparison with the data from the Chýnov Varied Unit. Photographs showing the
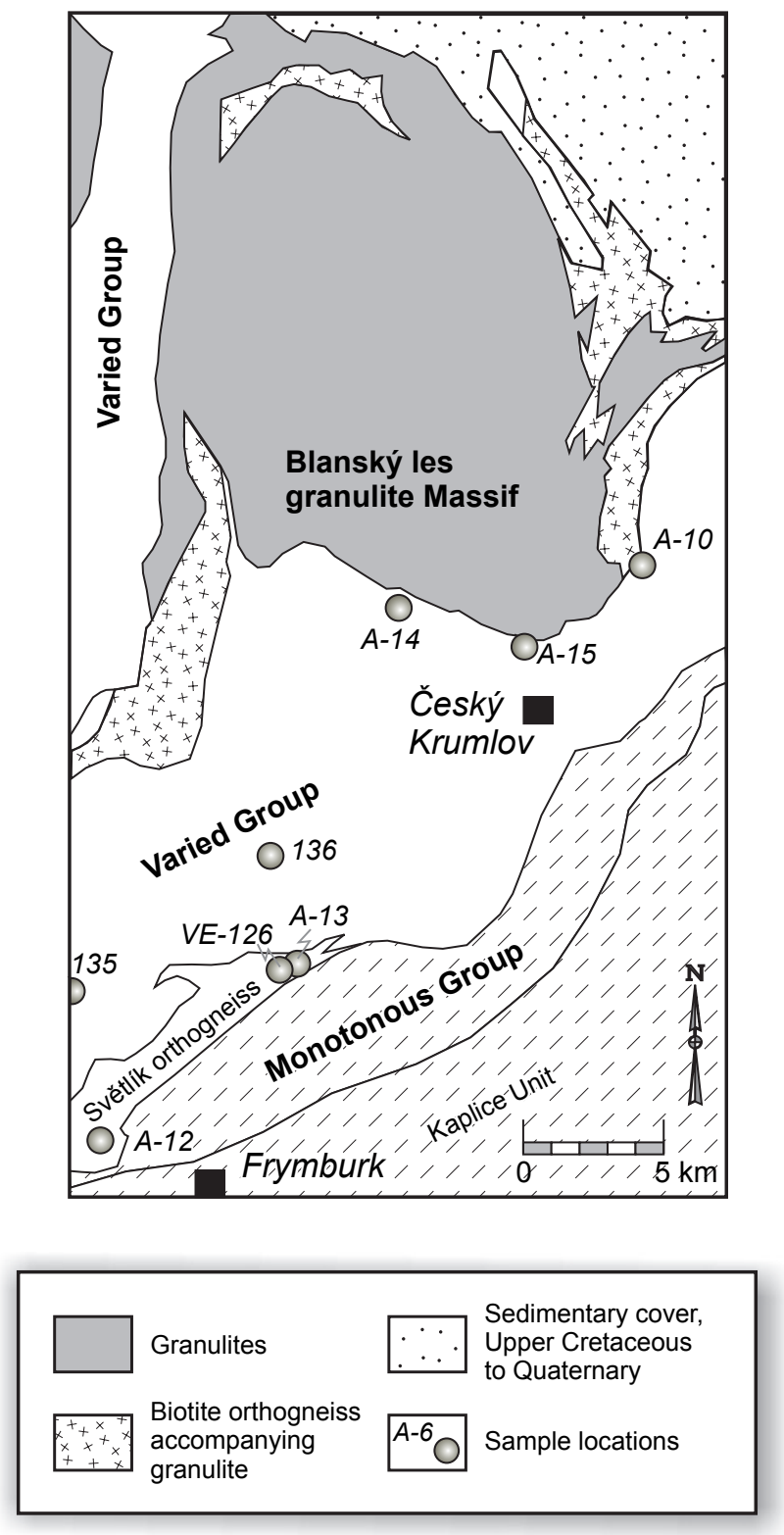

Fig. 3 Sample location and simplified geological sketch of the Český Krumlov area. Adopted from Czech Geological Survey map $1: 50000$.

variable textures of samples from the Český Krumlov area are presented in Fig. 4.

\subsubsection{Amphibolites}

The amphibolite samples studied come from a variety of geological settings: A-10 (Zlatá Koruna) from near the Blanský les Granulite Massif; both A-14 (Lazec) and A15 (Vyšný) from the northern, and 135 (Lískovec) with 136 (Hořice na Šumavě) from the SW parts of the Český Krumlov Varied Unit (Fig. 3). 

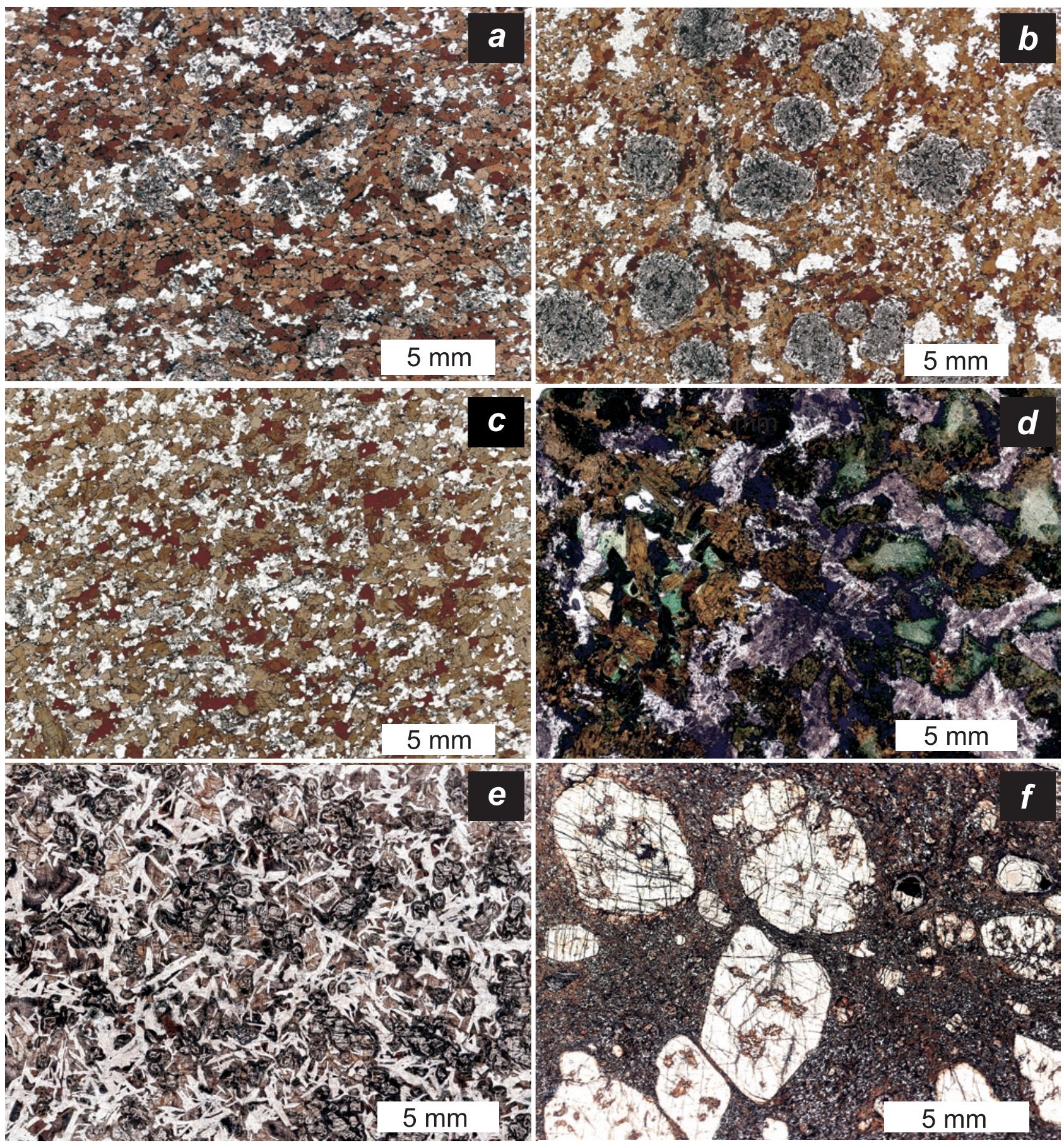

Fig. 4 Textures of amphibolites and metadolerites/metagabbros from the Český Krumlov area. a - A-10 Zlatá Koruna, amphibolite, b - A-14 Lazec, garnet amphibolite, c - A-15 Vyšný, amphibolite, d - A-12 Kovářov, amphibole metagabbro, e - A-13 Světlík, olivine metadolerite, f - VE-126 Světlík, porphyritic olivine-pyroxene metadolerite. All photographs represent scanned thin sections.

A-10 Zlatá Koruna, rock outcrop in the Vltava river valley, in forest c. $400 \mathrm{~m} \mathrm{~W}$ of Zlatá Koruna abbey, $48^{\circ} 51$ '18.49” $N$; 14²1'48.13" E

This sample is a garnet amphibolite with sulphides forming several-metres thick layers in biotite migmatite.
A-14 waste dump of graphite mine NE of Lazec, $5 \mathrm{~km}$ $N W$ of the centre of Český Krumlov, 48 50 '6.67" $N$; $14^{\circ} 16^{\prime} 15.45^{\prime \prime} \mathrm{E}$

The amphibolites in the Lazec graphite mine occur as a part of a varied assemblage of graphite gneiss, 
amphibolite and marble. The garnet amphibolites similar to sample A-14 are associated with dolomite-calcite marble with the mineral assemblage forsterite - spinel - clinohumite (chondrodite?) - phlogopite + brucite pseudomorphs after periclase.

A-15 Vyšný, disused marble quarry, $3 \mathrm{~km} \mathrm{NW}$ of the cen-

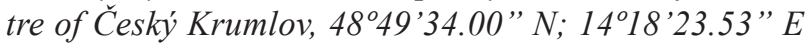

This sample comes from clinopyroxene-bearing amphibolite layers in marble in a disused quarry at Vyšný. The amphibolites form infrequent layers or boudins, very often with thin $(<1 \mathrm{~cm})$ diopside-rich reaction rims at the amphibolite-marble interface.

135 Liskovec, amphibolite quarry at Liskovec Hill (805 m a.s.l.), $500 \mathrm{~m} W$ of Bližná, 48 $43^{\prime} 21.88^{\prime \prime} N$; $14^{\circ} 5^{\prime} 16.96^{\prime \prime} \mathrm{E}$

136 Hořice na Šumavě, amphibolite outcrop $400 \mathrm{mE}$ of

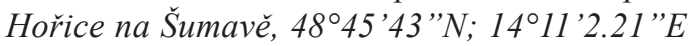

Both samples come from amphibolite intercalations in amphibole-biotite paragneisses.

\subsubsection{Metadolerites and metagabbros}

A-13 boulders in fields, $1.5 \mathrm{~km} W$ of the village of Svertlik, $0.3 \mathrm{~km} S$ of the road Svétlik-Muckov, 48 $43^{\circ} 56.03^{\prime \prime} \mathrm{N}$; $14^{\circ} 12$ '9.92" $E$

$V E-126$ boulders in fields, $1.5 \mathrm{~km} \mathrm{~W}$ of the village of Svétlík, 4843'48.89" N; 14'12'9.06" E

The coronitic metadolerite A-13 and porphyritic metadolerite VE-126 occur as dykes in the Světlík orthogneiss, with a Palaeoproterozoic protolith 2.1 Ga old (Wendt et al. 1993; Patočka et al. 2003). This mode of occurrence was important for preservation of the primary textures and for minimal recrystallization of dolerite dykes, which nevertheless were transformed to foliated amphibolite in local shear zones. Poor exposure did not permit study of field relations to the country rocks or possible compositional variation often encountered in intrusive sills of the less disturbed and better exposed terrains.

A-12 Plánský vrch, boulders and small rock outcrops in forest $400 \mathrm{~m}$ NE of Kovárov, 48 41'41.4" N; $14^{\circ} 7^{\prime} 34.41^{\prime \prime} \mathrm{E}$

Sample of a coarse-grained, foliated metagabbro A-12 comes from a partly sheared dyke about $1 \mathrm{~km}$ long, intruded in biotite migmatite and biotite orthogneiss of granitic composition. The orthogneiss remains undated but possibly correlates with the Palaeoproterozoic Světlík orthogneiss, which has dominantly a composition of amphibole-biotite tonalite or diorite. In outcrop the foliated metagabbro grading to amphibolite is seen as $\mathrm{cm}$ to metre wide shear zones alternating with massive, unfoliated metagabbro.

\section{Petrology and mineral chemistry}

\subsection{Amphibolites from the Chýnov Varied Unit}

\section{A-1 Obratan̆, fine-grained amphibolite}

The rock contains $\sim 60$ vol. \% of grey-green magnesiohornblende (Tab. 1, Fig. 5) and $\sim 40$ vol. $\%$ of intermediate plagioclase. Opaque minerals are almost exclusively ilmenite ( 1 vol. \%); titanite, zircon and chlorite are accessory.

\section{A-2 Pacovská hora Hill, fine-grained amphibolite}

The sample contains $\sim 45$ vol. \% of green edenite, $50 \mathrm{vol}$ \% intermediate plagioclase forming often oikocrysts enclosing abundant ilmenite, and $\sim 5 \%$ opaque minerals. Amphibole shows a tendency to poikiloblastic growth of somewhat larger grains. Biotite, titanite and apatite are accessory. The opaque minerals comprise c. $2 / 3$ of ilmenite containing $~ 15 \%$ of unmixed lenticular hematite, $1 / 3$ of magnetite formed by oxidation of pyrrhotite and carrying minute chalcopyrite inclusions inherited from pyrrhotite, minor residual pyrrhotite and traces of sphalerite.

\section{A-3 Pacovská hora Hill, fine-grained amphibolite}

The petrography of this sample is very similar to A-2, including quantitative ratio of edenite and plagioclase, and the presence of accessory minerals with traces of chalcopyrite and sphalerite. However, opaque minerals are absolutely dominated by ilmenite, with unmixed hematite accounting only for 2.5 vol. \%. The fabric of ilmenite inclusions in somewhat coarser plagioclase indicates $\mathrm{s}_{\mathrm{i}} / / \mathrm{s}_{\mathrm{e}}$ relations and points to prolonged plagioclase growth. Titanite, apatite, zircon and chlorite are accessory.

\section{A-4 Pacovská hora Hill, fine-grained amphibolite}

The petrography is very similar to that of samples A-2 and A-3. The bluish-green amphibole is edenite associated with intermediate plagioclase. Accessory minerals are quartz, biotite, titanite, apatite, chlorite $($ each $<1 \%)$ and opaque minerals. The opaque phases $(4$ vol. $\%)$ are dominated by ilmenite (3/4) with 15 vol. $\%$ of unmixed hematite, magnetite $(1 / 10)$, pyrrhotite $(1 / 7)$ plus traces of chalcopyrite and sphalerite.

\section{A-5 Pacovská hora Hill, fine-grained amphibolite}

The rock contains $\sim 35$ vol. \% of bluish-green ferropargasite to ferrohornblende, $55 \%$ intermediate plagioclase, $8 \%$ diopsidic pyroxene in equilibrium with other minerals, $5 \%$ titanite and $3 \%$ carbonate. Apatite, chlorite and opaque minerals are accessory. The opaque minerals ( $1 \%$ ) include $1 / 5$ ilmenite, $2 / 5$ magnetite, $1 / 5$ pyrrhotite plus traces of chalcopyrite and sphalerite. 
Table 1a Representative analyses of amphibole from the Chýnov area amphibolites (wt. \%) recalculated on the basis of $23(\mathrm{O}, \mathrm{OH})$ equivalents.

\begin{tabular}{|c|c|c|c|c|c|c|c|c|c|c|}
\hline Sample No. & $\mathrm{A} 2$ & A2 & A5 & A5 & A4 & A4 & A1 & A1 & A7 & A7 \\
\hline Analysis No. & Ch1 & $\mathrm{Ch} 2$ & Ch3 & $\mathrm{Ch} 4$ & Ch5 & Ch6 & $\mathrm{Ch} 7$ & $\mathrm{Ch} 8$ & Ch9 & Ch10 \\
\hline $\mathrm{SiO}_{2}$ & 44.94 & 43.57 & 43.05 & 40.98 & 44.15 & 43.07 & 47.46 & 45.04 & 48.65 & 42.79 \\
\hline $\mathrm{TiO}_{2}$ & 0.72 & 0.77 & 1.31 & 1.08 & 0.82 & 0.77 & 0.86 & 0.43 & 0.45 & 0.56 \\
\hline $\mathrm{Al}_{2} \mathrm{O}_{3}$ & 10.92 & 11.68 & 12.04 & 11.52 & 10.93 & 12.19 & 10.29 & 14.50 & 8.03 & 11.58 \\
\hline $\mathrm{Cr}_{2} \mathrm{O}_{3}$ & 0.07 & NA & NA & NA & 0.02 & 0.08 & 0.12 & 0.02 & 0.19 & 0.20 \\
\hline $\mathrm{FeOt}$ & 15.11 & 15.83 & 18.81 & 18.75 & 15.73 & 16.03 & 12.10 & 12.89 & 10.45 & 12.20 \\
\hline $\mathrm{MnO}$ & 0.25 & 0.22 & 0.35 & 0.37 & 0.16 & 0.20 & 0.08 & 0.07 & 0.15 & 0.12 \\
\hline $\mathrm{MgO}$ & 12.21 & 11.78 & 8.50 & 9.12 & 11.33 & 10.88 & 14.19 & 12.34 & 15.61 & 13.04 \\
\hline $\mathrm{CaO}$ & 11.13 & 10.79 & 11.89 & 11.37 & 11.62 & 11.72 & 11.89 & 11.67 & 12.08 & 13.14 \\
\hline $\mathrm{Na}_{2} \mathrm{O}$ & 1.66 & 2.11 & 1.02 & 2.08 & 1.41 & 1.44 & 1.26 & 1.58 & 1.45 & 1.91 \\
\hline $\mathrm{K}_{2} \mathrm{O}$ & 0.24 & 0.25 & 1.18 & 1.14 & 0.51 & 0.56 & 0.20 & 0.25 & 0.28 & 0.49 \\
\hline Total & 97.25 & 97.00 & 98.15 & 96.41 & 96.68 & 96.94 & 98.45 & 98.79 & 97.34 & 96.03 \\
\hline \multicolumn{11}{|c|}{ Number of atoms } \\
\hline $\mathrm{Si}$ & 6.665 & 6.520 & 6.491 & 6.348 & 6.628 & 6.472 & 6.823 & 6.482 & 7.035 & 6.427 \\
\hline $\mathrm{Al}$ & 1.335 & 1.480 & 1.509 & 1.652 & 1.372 & 1.528 & 1.177 & 1.518 & 0.965 & 1.573 \\
\hline $\mathrm{T}$ & 8.000 & 8.000 & 8.000 & 8.000 & 8.000 & 8.000 & 8.000 & 8.000 & 8.000 & 8.000 \\
\hline $\mathrm{Al}$ & 0.573 & 0.580 & 0.631 & 0.452 & 0.562 & 0.632 & 0.567 & 0.941 & 0.403 & 0.478 \\
\hline $\mathrm{Ti}$ & 0.080 & 0.087 & 0.149 & 0.126 & 0.093 & 0.087 & 0.093 & 0.047 & 0.049 & 0.063 \\
\hline $\mathrm{Cr}$ & 0.008 & 0.000 & 0.000 & 0.000 & 0.002 & 0.010 & 0.014 & 0.002 & 0.022 & 0.024 \\
\hline $\mathrm{Mg}$ & 2.699 & 2.628 & 1.911 & 2.106 & 2.536 & 2.437 & 3.041 & 2.648 & 3.365 & 2.920 \\
\hline $\mathrm{Fe}^{2+}$ & 1.639 & 1.706 & 2.310 & 2.316 & 1.807 & 1.834 & 1.285 & 1.362 & 1.161 & 1.515 \\
\hline $\mathrm{C}$ & 5.000 & 5.000 & 5.000 & 5.000 & 5.000 & 5.000 & 5.000 & 5.000 & 5.000 & 5.000 \\
\hline $\mathrm{Mn}$ & 0.031 & 0.028 & 0.045 & 0.049 & 0.020 & 0.025 & 0.010 & 0.009 & 0.018 & 0.015 \\
\hline $\mathrm{Fe}^{2+}$ & 0.235 & 0.276 & 0.062 & 0.113 & 0.168 & 0.180 & 0.170 & 0.189 & 0.102 & 0.017 \\
\hline $\mathrm{Ca}$ & 1.733 & 1.697 & 1.893 & 1.838 & 1.812 & 1.794 & 1.821 & 1.800 & 1.872 & 1.968 \\
\hline $\mathrm{Na}$ & 0.000 & 0.000 & 0.000 & 0.000 & 0.000 & 0.000 & 0.000 & 0.003 & 0.008 & 0.000 \\
\hline B & 2.000 & 2.000 & 2.000 & 2.000 & 2.000 & 2.000 & 2.000 & 2.000 & 2.000 & 2.000 \\
\hline $\mathrm{Na}$ & 0.477 & 0.612 & 0.298 & 0.625 & 0.410 & 0.420 & 0.351 & 0.438 & 0.399 & 0.556 \\
\hline $\mathrm{Ca}$ & 0.035 & 0.033 & 0.028 & 0.049 & 0.057 & 0.093 & 0.011 & 0.000 & 0.000 & 0.147 \\
\hline K & 0.045 & 0.048 & 0.227 & 0.225 & 0.098 & 0.107 & 0.037 & 0.046 & 0.052 & 0.094 \\
\hline A & 0.558 & 1.000 & 1.000 & 1.000 & 1.000 & 1.000 & 1.000 & 1.000 & 1.000 & 1.000 \\
\hline $\mathrm{VcA}$ & 0.442 & 0.307 & 0.447 & 0.101 & 0.435 & 0.380 & 0.601 & 0.516 & 0.550 & 0.203 \\
\hline
\end{tabular}

\section{A-6 Kladrubská hora, fine-grained amphibolite}

The sample contains $\sim 55$ vol. \% green amphibole, $40 \%$ intermediate plagioclase, $4 \%$ quartz, with accessory titanite, apatite, carbonate and chlorite. Opaque minerals $(\sim 2$ vol. $\%)$ are represented by $3 / 10$ ilmenite with unmixed hematite, 4/10 magnetite, $2 / 10$ pyrrhotite, 1/10 chalcopyrite and traces of sphalerite.

\section{A-7 Šimpach, fine-grained amphibolite}

The amphibole in this sample shows a wide range in $\mathrm{Al} / \mathrm{Si}$ ratio. It is grey-green pargasite to magnesiohornblende ( $\sim 60$ vol. $\%$ ) with $\mathrm{Mg} / \mathrm{Fe}$ ratio somewhat higher than in the other samples. Plagioclase $(30 \%)$ of intermediate composition is in part concentrated in aggregates $1-3 \mathrm{~mm}$ across arranged parallel to the foliation. Clinopyroxene (5\%) is a coarser-grained early diopsidic $\mathrm{Cpx}_{\mathrm{I}}$ and local $\mathrm{Cpx}_{\mathrm{II}}$ with elevated $\mathrm{Fe} / \mathrm{Mg}$ ratio in symplectitic aggregates with plagioclase and zoisite, which may have formed by reaction of minor garnet (?). Accessory minerals include titanite, clinozoisite/zoisite and only $0.5 \%$ of opaque minerals (ilmenite, rutile and chalcopyrite).

\subsection{Amphibolites from the Český Krumlov Varied Unit}

\section{A-10 Zlatá Koruna, garnet amphibolite}

The sample is a garnet amphibolite with an assemblage amphibole + garnet + plagioclase; common accessories 

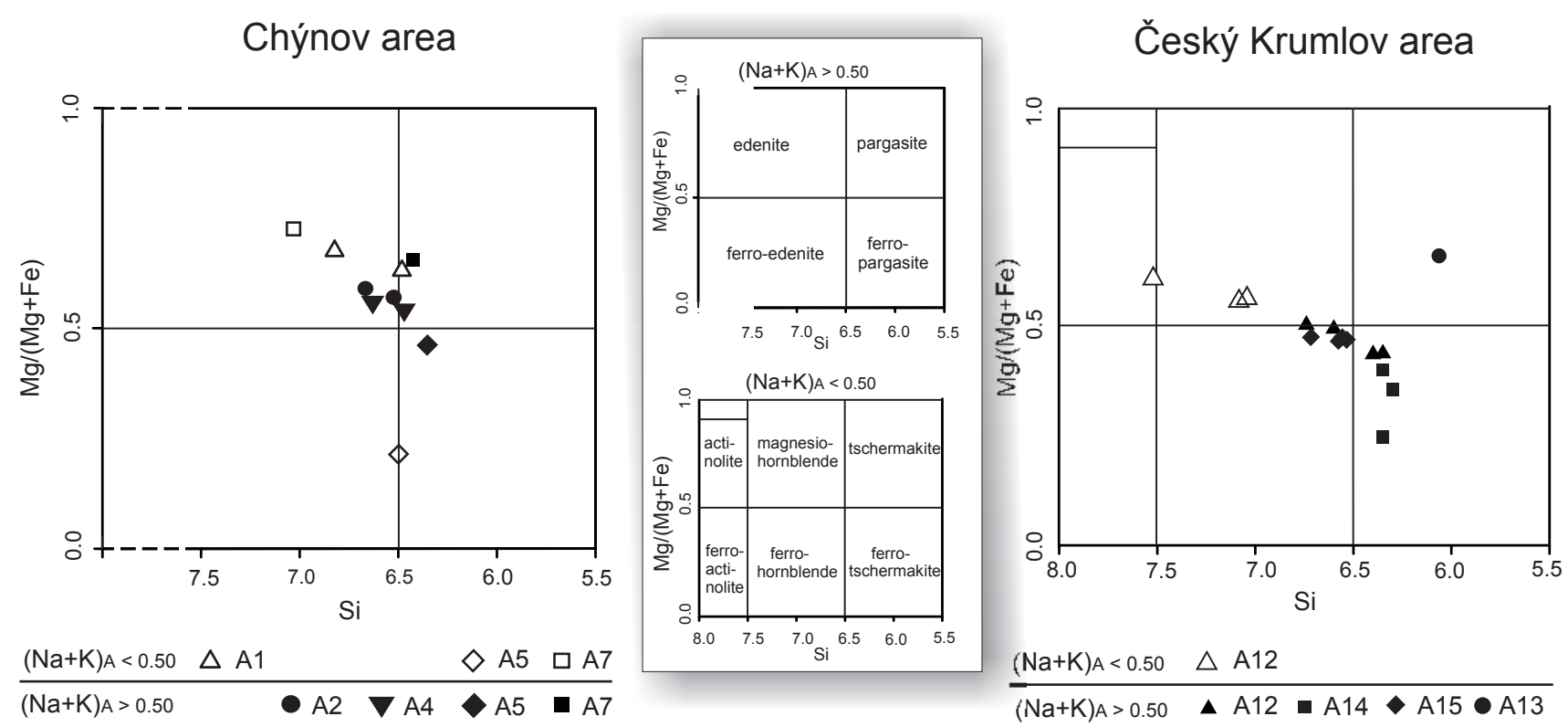

Fig. 5 Classification plot for the studied amphiboles (Leake et al. 1997). Total iron is calculated as $\mathrm{Fe}^{2+}$.

are ilmenite $(\sim 2 \%)$, apatite, minor sulphides, biotite and quartz; the rock has only indistinct foliation. Dark brown amphibole accounts for $c .55$ vol. \%, plagioclase with a strong inverse compositional zoning $30 \%$ and quartz $5 \%$. The granular matrix of amphibole and plagioclase $(0.2-1.0 \mathrm{~mm})$ contains grains of poikilitic garnet $0.2-1.0 \mathrm{~mm}$ across (Fig. 4a). Garnet forms c. $8 \%$ of the rock volume and encloses quartz, ilmenite and hornblende inclusions. Replacement of garnet by plagioclase is variable in extent.

\section{A-14 Lazec, garnet amphibolite}

The rock has a finely granular matrix $(0.1-0.5 \mathrm{~mm})$ with garnet porphyroblasts $2.5-3.5 \mathrm{~mm}$ across (Fig. $4 \mathrm{~b}$ ). Garnet appears to form c. $25 \mathrm{vol}$. \% of the rock but the garnets are strongly poikiloblastic with abundant plagioclase, ilmenite and titanite inclusions, so that the true garnet content is near $12 \%$. Amphibole accounts for c. $45 \%$, plagioclase $35 \%$ and quartz $8 \%$ of the rock volume. Accessory Ca-rich clinopyroxene is enclosed in garnet. The other important accessories are ilmenite, titanite, sulphides, apatite and carbonate. Dark brown amphibole is ferrotschermakite with $\mathrm{Al}^{\mathrm{IV}} 1.75-1.79$ apfu and the $\mathrm{Mg} / \mathrm{Fet}$ ratio is well inside the ferrotschermakite compositional field (Fig. 5, Tab. 2a). Plagioclase composition corresponds to andesine $\mathrm{An}_{36-37}$. Clinopyroxene is augite containing 30-32 mol. \% ferrosilite and 1.0-1.2 mol. \% jadeite (Tab. 2b). Garnet is almandine-grossular containing Alm $\mathrm{Al}_{52.8-54.5}, \mathrm{Grs}_{30.9-35.6}, \operatorname{Prp}_{6.9-7.2}, \mathrm{Adr}_{3.0-3.6}$, $\mathrm{Sps}_{1.5-3.5}$ mol. \% (Tab. 2c). The low Prp and high Grs contents probably indicate early crystallization of garnet at moderate temperature and increased pressure. Matrix mineral assemblage indicates equilibrium relations.

\section{A-15 Vyšný, clinopyroxene-bearing amphibolite}

This fine-grained rock $(0.5-1.5 \mathrm{~mm}$; Fig. 4c) contains c. 50-55 vol. \% of brown amphibole, $40 \%$ plagioclase, $6 \%$ Ca-clinopyroxene and $3 \%$ quartz. Ilmenite dominates the opaque minerals; titanite, apatite, sulphides and zircon are also common. Dark brown amphibole is ferrotschermakite with $\mathrm{Al}^{\mathrm{IV}} 1.50-1.63$ apfu and $\mathrm{Mg} / \mathrm{Fet}$ ratio near tschermakite compositional field. Plagioclase is andesine $\mathrm{An}_{36-46}$ (Tab. 2b). Clinopyroxene is colourless diopside-augite containing 19 mol. \% ferrosilite and 1.4-3.1 mol. \% jadeite.

\section{Liskovec, amphibolite}

Dark green (brownish green) amphibole and plagioclase $0.3-1.5 \mathrm{~mm}$ across form a regular granoblastic texture and a weak planar-preferred orientation. Amphibole makes $c .70$ vol. \%, plagioclase with a strong inverse zoning $25 \%$ and quartz $3 \%$ of the rock volume. Ilmenite, apatite and titanite are the common accessories.

\section{Hořice na Šumavě, amphibolite}

Brownish green (khaki) amphibole and plagioclase 0.3$1.3 \mathrm{~mm}$ form a regular granoblastic planar texture. The bulk of the rock consists of amphibole (60 vol. \%) and plagioclase with a strong inverse zoning (35\%). Quartz, rutile, ilmenite with minor apatite, sulphide, titanite, and biotite are common accessories. 
Table 1b Representative analyses of clinopyroxene, ilmenite and biotite from the Chýnov area amphibolites (wt. \%) recalculated on the basis of 4 cats, 2 cats and $22(\mathrm{O}, \mathrm{OH})$ equivalents, respectively.

\begin{tabular}{|c|c|c|c|c|c|c|c|}
\hline Mineral & Cpx & Cpx I & Cpx II & $\mathrm{Ilm}$ & $\mathrm{Ilm}$ & $\mathrm{Ilm}$ & $\mathrm{Bt}$ \\
\hline Sample No. & A5 & A7 & A7 & A4 & A1 & A2 & A4 \\
\hline Analysis No. & Ch11 & Ch12 & Ch13 & Ch15 & Ch16 & Ch17 & Ch14 \\
\hline $\mathrm{SiO}_{2}$ & 51.72 & 52.23 & 50.44 & 0.20 & 0.14 & 0.18 & 36.63 \\
\hline $\mathrm{TiO}_{2}$ & 0.09 & 0.21 & 0.16 & 49.59 & 50.68 & 48.89 & 2.50 \\
\hline $\mathrm{Al}_{2} \mathrm{O}_{3}$ & 1.90 & 2.31 & 2.32 & 0.09 & 0.00 & 0.05 & 14.89 \\
\hline $\mathrm{Cr}_{2} \mathrm{O}_{3}$ & 0.00 & 0.00 & 0.46 & 0.05 & 0.07 & 0.19 & 0.01 \\
\hline $\mathrm{FeOt}$ & 10.88 & 6.84 & 12.75 & 48.09 & 46.15 & 49.69 & 19.59 \\
\hline $\mathrm{MnO}$ & 0.59 & 0.20 & 0.33 & 0.71 & 0.41 & 0.67 & 0.00 \\
\hline $\mathrm{MgO}$ & 11.20 & 14.17 & 9.79 & 0.21 & 0.31 & 0.09 & 11.45 \\
\hline $\mathrm{NiO}$ & 0.00 & 0.00 & 0.00 & 0.12 & 0.08 & 0.25 & 0.12 \\
\hline $\mathrm{Na}_{2} \mathrm{O}$ & 0.71 & 0.48 & 0.65 & 0.00 & 0.00 & 0.05 & 0.02 \\
\hline $\mathrm{K}_{2} \mathrm{O}$ & 0.00 & 0.01 & 0.05 & 0.00 & 0.01 & 0.02 & 10.19 \\
\hline Total & 99.85 & 99.62 & 99.50 & 99.16 & 97.86 & 100.24 & 95.40 \\
\hline \multicolumn{8}{|c|}{ Number of atoms } \\
\hline $\mathrm{Si}$ & 1.950 & 1.937 & 1.928 & 0.005 & 0.004 & 0.005 & 5.64 \\
\hline $\mathrm{Ti}$ & 0.003 & 0.006 & 0.005 & 0.944 & 0.980 & 0.920 & 0.29 \\
\hline $\mathrm{Al}$ & 0.084 & 0.101 & 0.105 & 0.003 & - & 0.001 & 2.70 \\
\hline $\mathrm{Cr}$ & - & - & 0.014 & 0.001 & 0.001 & 0.004 & 0.00 \\
\hline $\mathrm{Fe}^{3+}$ & 0.062 & 0.049 & 0.068 & 0.097 & 0.032 & 0.148 & - \\
\hline $\mathrm{Fe}^{2+}$ & 0.281 & 0.163 & 0.339 & 0.921 & 0.960 & 0.892 & 2.52 \\
\hline Mn & 0.019 & 0.006 & 0.011 & 0.015 & 0.009 & 0.014 & - \\
\hline $\mathrm{Mg}$ & 0.629 & 0.783 & 0.558 & 0.008 & 0.012 & 0.003 & 2.63 \\
\hline $\mathrm{Ca}$ & 0.919 & 0.920 & 0.923 & 0.003 & - & 0.004 & - \\
\hline $\mathrm{Na}$ & 0.052 & 0.035 & 0.048 & - & - & 0.002 & 0.00 \\
\hline $\mathrm{K}$ & - & - & 0.002 & - & - & 0.001 & 2.00 \\
\hline
\end{tabular}

\subsection{Metadolerites/metagabbros from the Ceský Krumlov Varied Unit}

\section{A-12 Kovárov, foliated amphibole metagabbro}

The rock is fine- to medium-grained. Recrystallized matrix, including fine amphibole and plagioclase crystals, has a grain size $0.05-0.2 \mathrm{~mm}$ (Fig. 4d); relict grains of primary plagioclase are $1-3 \mathrm{~mm}$ across. Monomineralic granular pseudomorphs of magnesiohornblende after primary diopside-augite contain $0.56-0.66 \mathrm{Al}^{\mathrm{IV}}$ (apfu), which corresponds to a composition near the actinolite field (Fig. 5). The predominant brown-green amphibole is magnesio-hornblende to ferrotschermakite with $\mathrm{Al}^{\mathrm{IV}}$ 1.19-1.77 apfu. Plagioclase is largely preserved in cloudy relict grains, partly recrystallized to a fine-grained mosaic. Its composition varies between andesine $\mathrm{An}_{37}$ and labradorite $\mathrm{An}_{66}$ : newly formed albite $\mathrm{An}_{4}$ is rare. The to- tal plagioclase content is $40-45$ vol. \%. Locally chlorites up to $1 \mathrm{~mm}$ across form clusters in coarse brown-green amphibole. Other accessory minerals are titanite, opaque minerals, rare partly chloritized biotite, and apatite. The newly formed mineral assemblage corresponds to recrystallization under amphibolite-facies conditions. Minor chlorite and albite indicate local low temperature alterations, possibly due to an influx of hydrothermal fluids.

\section{A-13 Světlik, olivine-pyroxene metadolerite}

The rock shows outstandingly well preserved ophitic texture (Fig. 4e) with an average grain size $0.5-1 \mathrm{~mm}$ but some strongly poikilitic crystals of augite are 2 to $5 \mathrm{~mm}$ long. Lath-shaped plagioclase (c. $50 \mathrm{vol} . \%)$ and clinopyroxene $(30 \%)$ are fresh and free of alteration, though both phases show some clouding. Augite has $0.15 \mathrm{Al}^{\mathrm{IV}}$ apfu and $13.7 \mathrm{~mol}$ \% ferrosilite. Pleochroic 


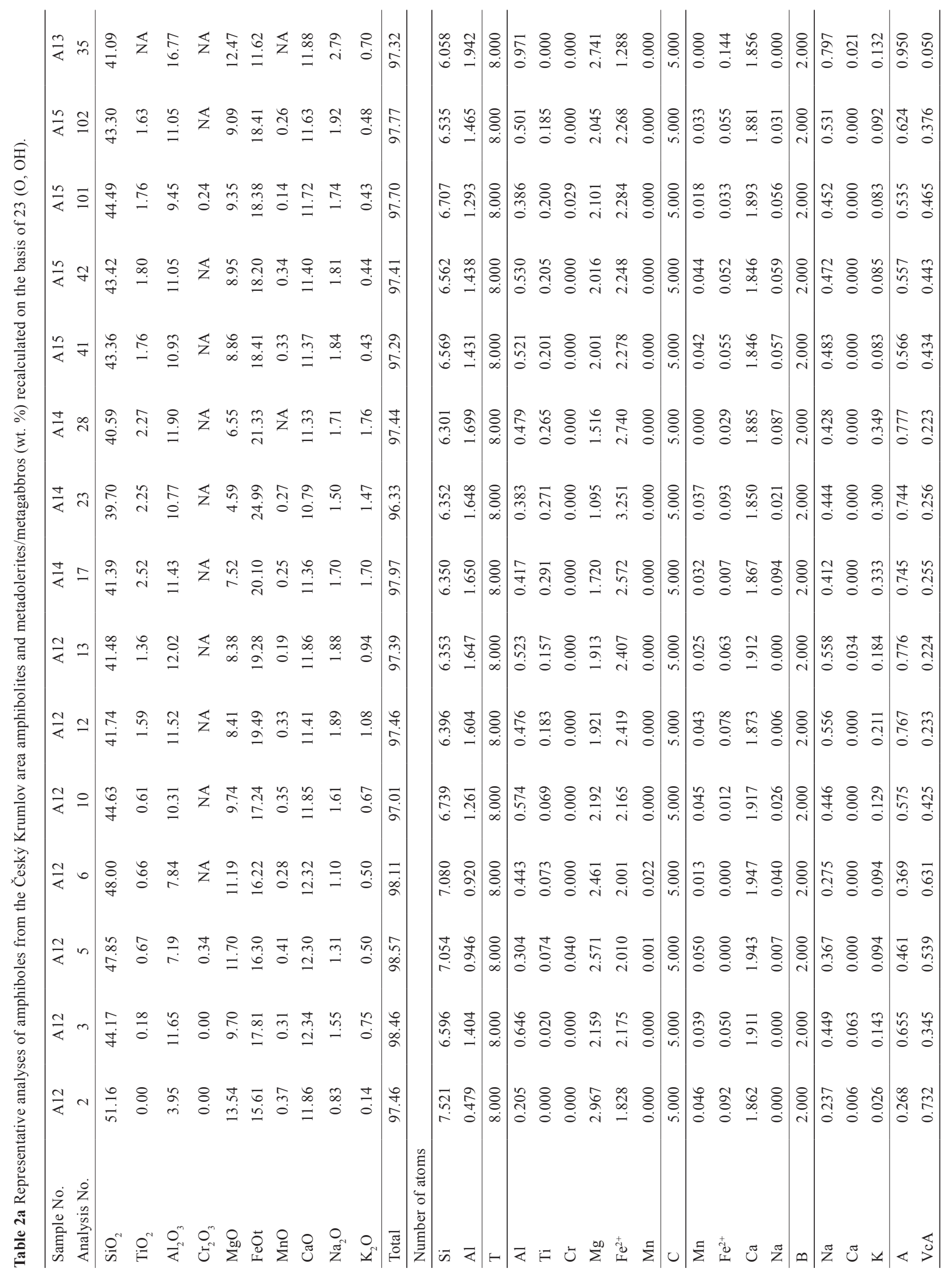




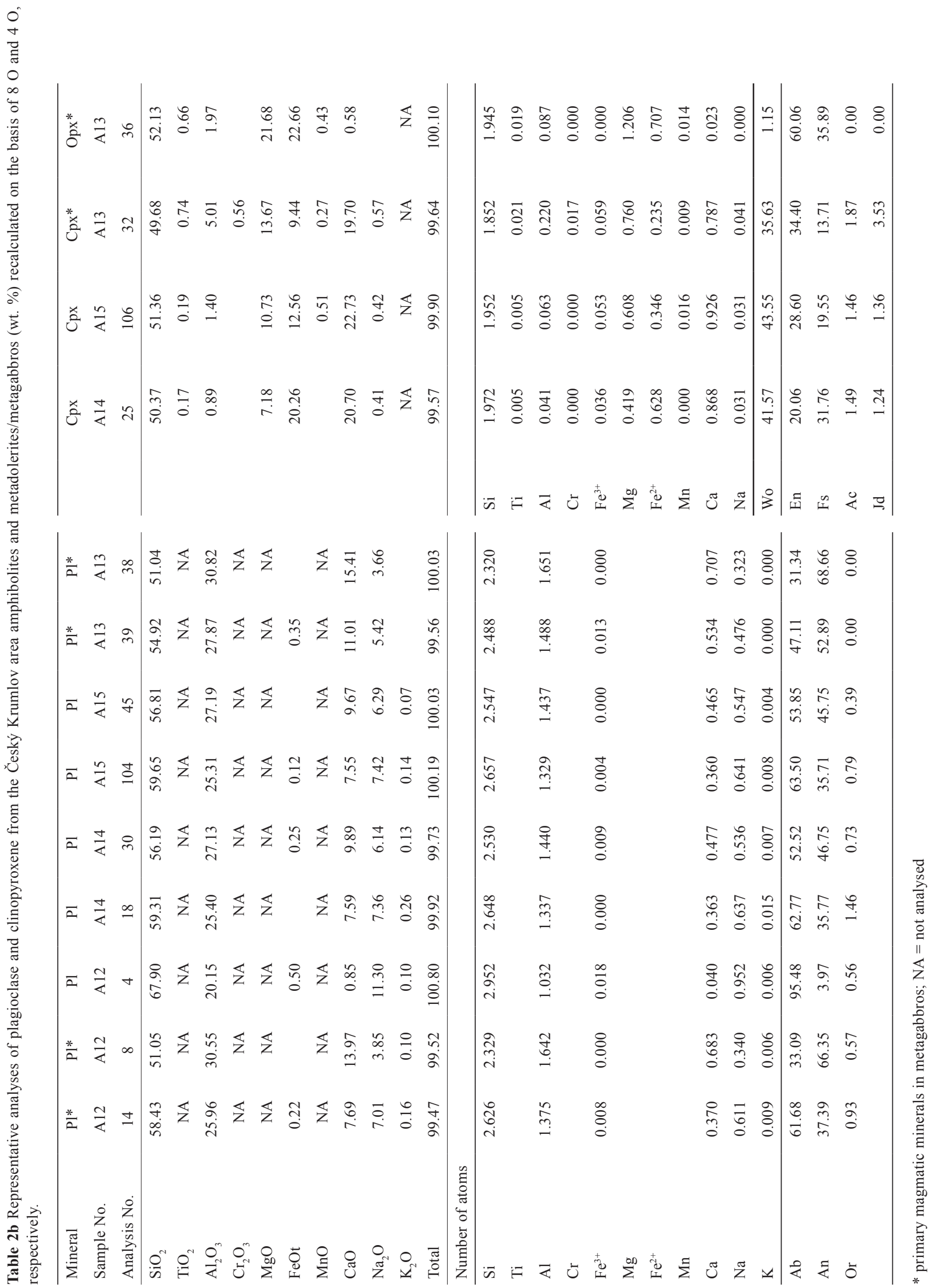


Table 2c Representative analyses of ilmenite, garnet and olivine from the Český Krumlov area amphibolites and metadolerites/metagabbros (wt. \%) recalculated on the basis of 2 cats, 8 cats and 3 cats, respectively.

\begin{tabular}{|c|c|c|c|c|c|c|c|c|c|c|}
\hline Mineral & Ilmenite & Ilmenite & Ilmenite* & Ilmenite* & & Grt & Grt & Grt & & Olivine* \\
\hline Sample No. & A14 & A 15 & A12 & A13 & & A 14 & A 14 & A 13 & & A13 \\
\hline Analysis No. & 27 & 107 & 15 & 40 & & 19 & 21 & 34 & & 31 \\
\hline $\mathrm{SiO}_{2}$ & 0.27 & & 0.28 & 0.22 & & 37.97 & 37.79 & 39.23 & & 36.19 \\
\hline $\mathrm{TiO}_{2}$ & 51.19 & 51.91 & 51.97 & 50.99 & & 0.16 & & & & \\
\hline $\mathrm{Al}_{2} \mathrm{O}_{3}$ & 0.11 & 0.14 & 0.11 & & & 20.67 & 20.53 & 21.58 & & \\
\hline $\mathrm{MgO}$ & 0.05 & 0.15 & & 0.48 & & 1.79 & 1.78 & 8.30 & & 27.87 \\
\hline $\mathrm{FeOt}$ & 46.29 & 46.29 & 45.49 & 47.00 & & 25.46 & 26.27 & 22.85 & & 35.71 \\
\hline $\mathrm{MnO}$ & 0.93 & 1.39 & 2.46 & 0.42 & & 0.67 & 1.62 & 1.22 & & 0.37 \\
\hline $\mathrm{CaO}$ & 0.30 & & & & & 13.30 & 11.58 & 6.44 & & \\
\hline Total & 99.14 & 99.88 & 100.31 & 99.10 & & 100.01 & 99.56 & 99.62 & & 100.14 \\
\hline \multicolumn{11}{|c|}{ Number of atoms } \\
\hline $\mathrm{Si}$ & 0.007 & 0.000 & 0.007 & 0.006 & & 2.999 & 3.008 & 3.011 & & 1.005 \\
\hline $\mathrm{Ti}$ & 0.977 & 0.985 & 0.982 & 0.972 & & 0.010 & 0.000 & 0.000 & & \\
\hline $\mathrm{Al}$ & 0.003 & 0.004 & 0.003 & 0.000 & & 1.924 & 1.926 & 1.952 & & \\
\hline $\mathrm{Mg}$ & 0.002 & 0.006 & 0.000 & 0.018 & & 0.211 & 0.211 & 0.950 & & 1.153 \\
\hline $\mathrm{Fe}^{3+}$ & 0.028 & 0.027 & 0.019 & 0.045 & & 0.067 & 0.074 & 0.048 & & \\
\hline $\mathrm{Fe}^{2+}$ & 0.954 & 0.949 & 0.937 & 0.950 & & 1.615 & 1.675 & 1.419 & & 0.829 \\
\hline Mn & 0.020 & 0.030 & 0.052 & 0.009 & & 0.045 & 0.109 & 0.079 & & 0.009 \\
\hline \multirow[t]{6}{*}{$\mathrm{Ca}$} & 0.008 & 0.000 & 0.000 & 0.000 & & 1.126 & 0.988 & 0.530 & & \\
\hline & & & & & Prp & 6.89 & 6.85 & 30.94 & Fo & 57.93 \\
\hline & & & & & Alm & 52.79 & 54.36 & 46.23 & $\mathrm{Fa}$ & 41.64 \\
\hline & & & & & Sps & 1.47 & 3.54 & 2.58 & Tep & 0.44 \\
\hline & & & & & Adr & 3.28 & 3.56 & 2.31 & & \\
\hline & & & & & Grs & 35.57 & 30.87 & 16.84 & & \\
\hline
\end{tabular}

* primary magmatic minerals in metagabbros

red-brown orthopyroxene (parallel to Z) is an accessory component; it contains 35.9 mol. \% ferrosilite and 0.06 apfu $\mathrm{Al}^{\mathrm{IV}}$. Olivine grains $0.5-1.5 \mathrm{~mm}$ in diameter exhibit two regular kelyphitic reaction zones $0.2-0.3 \mathrm{~mm}$ wide. The inner zone is of enstatite containing $32 \mathrm{~mol}$. \% ferrosilite with $\mathrm{Al}^{\mathrm{IV}} 0.04 \mathrm{apfu}$, oriented perpendicular to the olivine surface. The outer zone is composed of a microcrystalline aggregate of grey-green tschermakite (Fig. 5) with minute spinel crystals $<2 \mu \mathrm{m}$. The amphibole has 2.0 $\mathrm{Al}^{\mathrm{IV}}$ apfu, but part of the $\mathrm{Al}$ is in spinel microcrysts and analysis No. 35 (Tab. 2a) is not strictly monomineralic. Minor garnet crystals, $10-20 \mu \mathrm{m}$ in size, with a composition of $\mathrm{Alm}_{46.2}, \operatorname{Prp}_{30.9}, \mathrm{Grs}_{16.8}, \mathrm{Adr}_{2.3}$ and $\mathrm{Sps}_{2.6}$ mol. \% occur at the interface of the inner Opx and outer amphibole zone. Olivine inside these kelyphitic shells is fresh, containing $41.6 \mathrm{~mol}$. \% fayalite. The original olivine content prior to alteration could have been near 20 vol. \%. Accessory phases include primary ilmenite and titanomagnetite, minor primary red-brown biotite and apatite. The kelyphite zones around olivine and minor garnet of the given composition indicate partial (local) metamorphic reactions corresponding to highertemperature amphibolite-facies conditions at rather low fluid activity.

VE-126 Světlik, olivine-pyroxene porphyritic metadolerite

This rock, nominally similar to sample A-13, has a significantly different chemical composition with $17.43 \mathrm{wt}$ \% $\mathrm{MgO}$ (Tab. 3). Its highly magnesian composition reflects the abundance of phenocrysts of clinopyroxene and olivine up to $12 \mathrm{~mm}$ long, accounting for $c .20-30 \%$ of the rock volume (Fig. 4f).

The rock can be interpreted as having crystallized from a melt containing a significant proportion of pyroxeneolivine cumulate. The preservation of the primary minerals is surprisingly good, as in sample A-13, which it also resembles in having two kelyphitic zones around olivine and minor, newly formed garnet. The metamorphic characteristics are also similar to sample A-13. 
Table 3 Major- and minor-element whole-rock geochemical analyses for the metabasic rocks from the South Bohemian Varied Group (wt. \%)

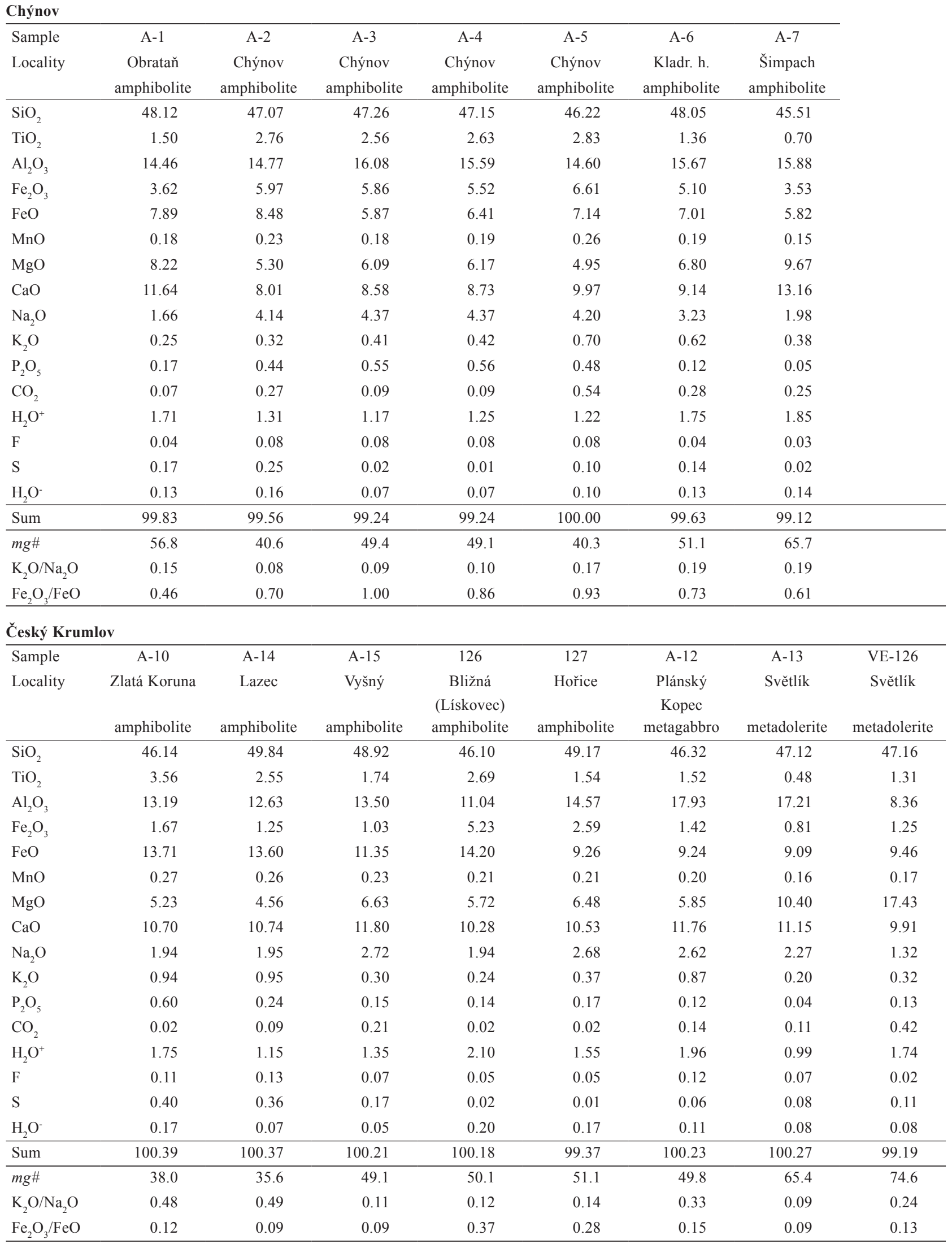




\section{Whole-rock geochemistry}

\subsection{Rock classification}

The newly-obtained major- and minor-element analyses for the metabasic rocks from the South Bohemian Varied Unit (Tab. 3) have been supplemented by data from Němec (1998), René (2007) (amphibolites from around Chýnov) and Patočka (1991) (amphibolites of the Český Krumlov Varied Unit). In view of their association with marble, the question of whether these could not be paraamphibolites of Fe-rich dolomitic origin needs to be discussed. In fact the chemical indicators all consistently show that the studied rocks are orthoamphibolites. For instance, in the diagram $\mathrm{Ni}$ vs. $\mathrm{Zr} / \mathrm{TiO}_{2}$ of Winchester et al. (1980) (not shown), all the analyses plot below the dividing line, separating the fields for metabasic rocks with the sedimentary (higher $\mathrm{Zr} / \mathrm{TiO}_{2}$ at the given $\mathrm{Ni}$ contents) and igneous parentage.

On a standard Total Alkali-Silica (TAS) diagram of Le Bas et al. (1986) (Fig. 6a), the metavolcanics classify exclusively as basalts. Most data points fall beneath the dividing line between the alkaline and subalkaline (tholeiitic/calc-alkaline) domains as defined by Irvine and Baragar (1971). Analyses with alkaline affinity are considerably rarer; only samples A-2, A-3, A-4 and A-5 in our data set classify as such.

However, for metamorphosed basic volcanic rocks, the mobility of elements with low ionic potential is a major concern. Therefore, immobile elements, such as HFSE, are preferred for classification purposes (Winchester and Floyd 1976; Floyd and Winchester 1978). A popular diagram utilizing relatively immobile element ratios $(\mathrm{Nb} / \mathrm{Y}$ vs. $\mathrm{Zr} / \mathrm{Ti})$ was proposed by Winchester and Floyd (1977). As it was designed before publication of the TAS diagram, the field definition for the $\mathrm{Nb} / \mathrm{Y}$ vs. $\mathrm{Zr} / \mathrm{Ti}$ plot was subsequently modified by Pearce (1996) and this form of the plot is preferred here (Fig. 6b). All rocks are again basaltic in composition; the elevated $\mathrm{Nb} / \mathrm{Y}$ ratios of samples A-3, A-4, A-10 and A-12 indicate their alkaline nature. The $\mathrm{Nb} / \mathrm{Y}$ ratio of amphibolite A-7 is an estimate only, as the $\mathrm{Nb}$ is below the detection limit of $0.5 \mathrm{ppm}$ and thus its $\mathrm{Nb} / \mathrm{Y}$ should be $<0.027$.

The tholeiitic (and not calc-alkaline) affinity of the subalkaline part of the dataset is documented by the AFM ternary plot of Irvine and Baragar (1971) (Fig. 6c) and is confirmed using less mobile elements in the multicationic ternary plot $\mathrm{Al}-\mathrm{Fe}^{\mathrm{T}}+\mathrm{Ti}-\mathrm{Mg}$ of Jensen (1976) (Fig. 6d).

\subsection{Major elements}

The newly obtained data for the amphibolites confirm that we are dealing exclusively with basic rocks $\left(\mathrm{SiO}_{2}=\right.$
45.51-49.84 wt. \%, the least siliceous being the Chýnov sample A-5). The mg numbers $[m g \#=$ molar $\mathrm{Mg} /(\mathrm{Mg}+$ $\left.\mathrm{Fe}_{\mathrm{t}}\right)$ ] span a fairly wide range, indicating a variable - but usually rather high - degree of fractionation: 35.6 (A-14) to 65.7 (A-7). The $m g \#$ for the metadolerites/metagabbros are even more variable (49.8-74.6).

As often so with basic igneous rocks, $\mathrm{MgO}$ seems to be a more appropriate fractionation index than silica. The $\mathrm{MgO}$ variation is fairly large (4.56-9.67 wt. \%; the lowest content being in the Chýnov sample A-5, the highest in amphibolite A-7 from Šimpach). Some of the metadolerites/metagabbros have even higher $\mathrm{MgO}$ contents (5.85-17.43).

Binary plots of $\mathrm{MgO}$ versus oxides of major- and minor elements (sometimes termed Fenner plots) are shown in Fig. 7a. Some diagrams are characterised by nearly linear negative $\left(\mathrm{TiO}_{2}\right.$ and $\left.\mathrm{FeO}_{\mathrm{t}}\right)$ or positive $(\mathrm{CaO}$ and $\mathrm{Al}_{2} \mathrm{O}_{3}$ ) trends, while others feature an inflection at $\mathrm{MgO} \sim$ $6.5-7.0$ wt. \% $\left(\mathrm{SiO}_{2}, \mathrm{P}_{2} \mathrm{O}_{5}\right)$. For instance the silica shows an initial increase with decreasing $\mathrm{MgO}$ (increasing degree of fractionation), and at around $\mathrm{MgO} \sim 7$ wt. \% the trend breaks into a strongly positive one.

The $\mathrm{K}_{2} \mathrm{O} / \mathrm{Na}_{2} \mathrm{O}$ ratios for the studied metabasites are variably low (0.08-0.49), and, except for samples A-10 and $\mathrm{A}-14$, are all under 0.20 . But, as sodium is a highly mobile element, the $\mathrm{K}_{2} \mathrm{O} / \mathrm{Na}_{2} \mathrm{O}$ ratios may reflect metamorphic modification rather than primary igneous variation. Indeed, as expected in such a high-grade metamorphic terrain, $\mathrm{Na}_{2} \mathrm{O}$ fails to define any clear trend and $\mathrm{K}_{2} \mathrm{O}$ yields only a rough negative correlation with $\mathrm{MgO}$.

The degree of $\mathrm{Fe}$ oxidation is highly variable. The Chýnov samples are in general more oxidized, especially the alkaline types $\left(\mathrm{Fe}_{2} \mathrm{O}_{3} / \mathrm{FeO}=0.86-1.00\right.$ : A-3, A-4; Tab. 3) followed by the other two samples from the Pod Pacovou horou quarry $\left(\mathrm{Fe}_{2} \mathrm{O}_{3} / \mathrm{FeO}=0.70-0.93\right.$ : A-2, A-5). The least oxidized of the Chýnov set are samples A-1, A-7 and A-6 $\left(\mathrm{Fe}_{2} \mathrm{O}_{3} / \mathrm{FeO}=0.46-0.73\right)$. By contrast, the Český Krumlov metabasic rocks have low $\mathrm{Fe}_{2} \mathrm{O}_{3} / \mathrm{FeO}$ ratios $(<0.4)$, which, except for amphibolites 126 and 127, does not exceed 0.15 .

The box plots shown in Fig. 7b underpin several important differences between the amphibolites from the Chýnov and Český Krumlov varied units, some already apparent from the Fenner plots. Please note that only new analyses obtained by identical methods in the same laboratories were used here for the sake of reproducibility. The Český Krumlov amphibolites clearly tend to have considerably lower $\mathrm{Al}_{2} \mathrm{O}_{3}, \mathrm{Na}_{2} \mathrm{O}$ and $\mathrm{Fe}_{2} \mathrm{O}_{3} / \mathrm{FeO}$ and higher $\mathrm{FeO}_{\mathrm{t}}, \mathrm{CaO}$ and $\mathrm{MnO}$ contents than those from Chýnov.

\subsection{Trace elements}

The trace-element contents and evolution with progressive differentiation are shown in binary plots with $\mathrm{MgO}$ 

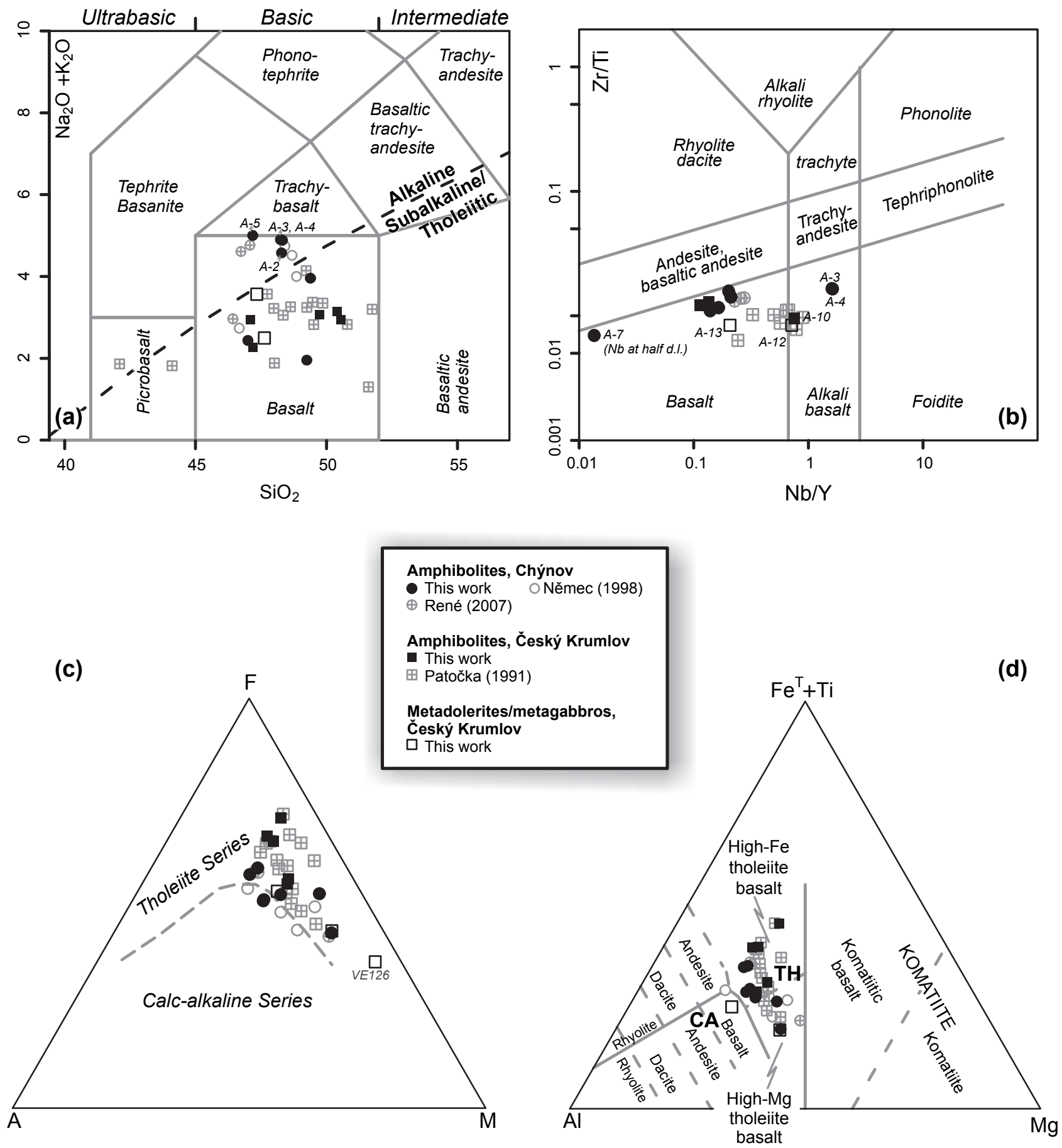

Fig. 6a - Diagram $\mathrm{SiO}_{2}-\left(\mathrm{Na}_{2} \mathrm{O}+\mathrm{K}_{2} \mathrm{O}\right)(\mathrm{TAS})$ of Le Bas et al (1986). The dividing line between the subalkaline and alkaline domains is after Irvine and Baragar (1971). $\mathbf{b}$ - Classification plot $\mathrm{Nb} / \mathrm{Y}$ vs. $\mathrm{Zr} / \mathrm{Ti}$ after Pearce (1996), in which almost all the samples classify as subalkaline basalts. c - AFM diagram $\left(\mathrm{A}=\mathrm{Na}_{2} \mathrm{O}+\mathrm{K}_{2} \mathrm{O}, \mathrm{F}=\mathrm{FeO}_{t}, \mathrm{M}=\mathrm{MgO}\right.$ : Irvine and Baragar 1971) illustrating the tholeiitic trend shown by the south Bohemian metabasites. d - Cationic plot $\mathrm{Al}-\mathrm{Fe}^{\mathrm{T}}+\mathrm{Ti}-\mathrm{Mg}$ of Jensen (1996) confirming the tholeiitic character of the subalkaline amphibolites.

on abscissa (Fig. 8a). Fairly good positive trends are observed in diagrams involving compatible elements (transition metals $\mathrm{Cr}$ and $\mathrm{Ni}$ ). The $\mathrm{Cr}$ and $\mathrm{Ni}$ contents in some samples are high, reaching their maxima in the
Šimpach amphibolite A-7 $(\mathrm{Cr}=363$ and $\mathrm{Ni}=262 \mathrm{ppm}$; Tab. 4a). This probably indicates a considerable proportion of cumulus olivine and magnetite in this rock (e.g., Pearce 1996). All the amphibolite samples, regardless the 
(a)
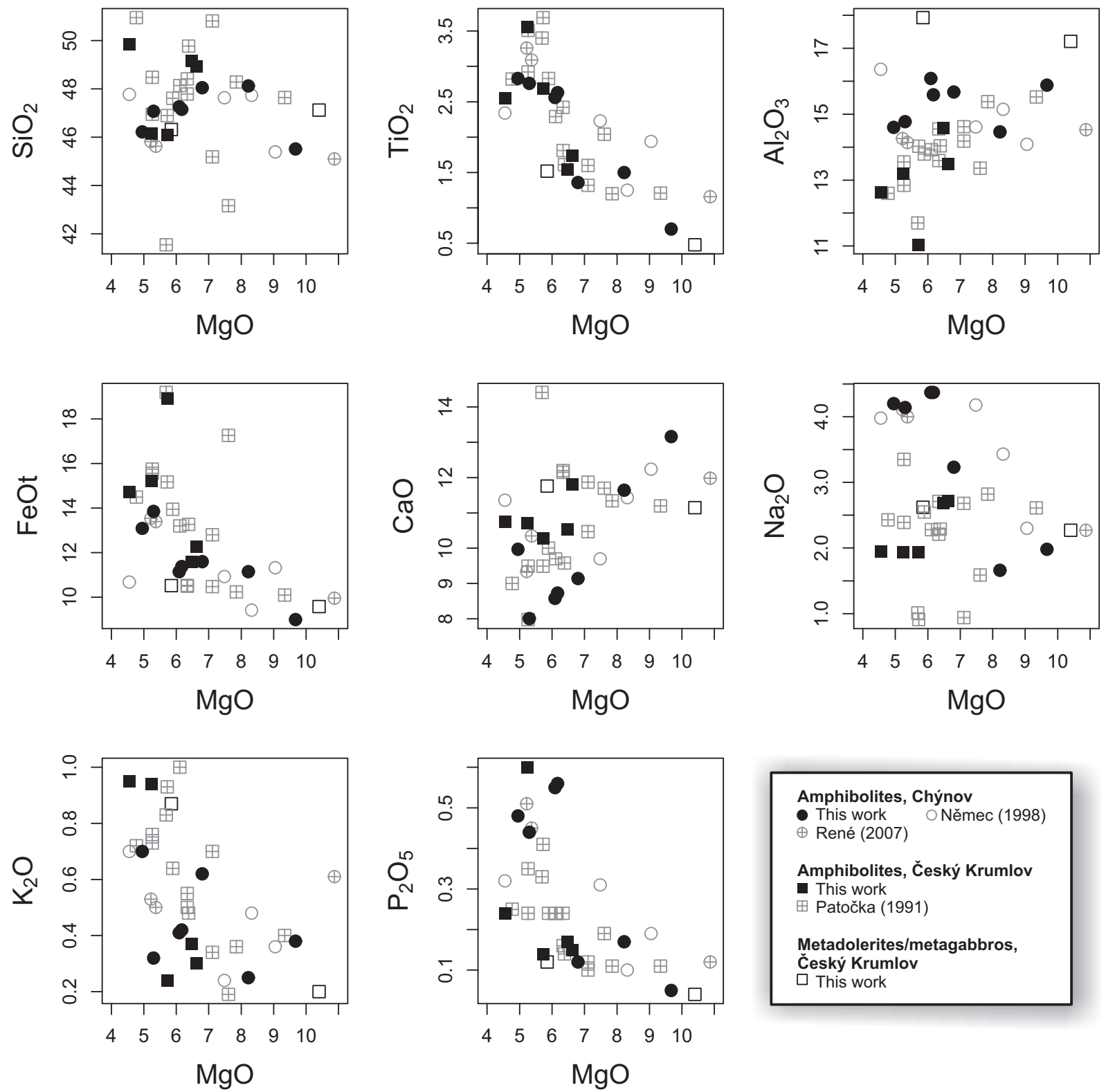

Amphibolites, Chýnov

- This work ONěmec (1998)

René (2007)

Amphibolites, Český Krumlov

- This work

$\boxplus$ Patočka (1991)

Metadolerites/metagabbros,

Ceský Krumlov

$\square$ This work

(b) $\mathrm{CaO}$
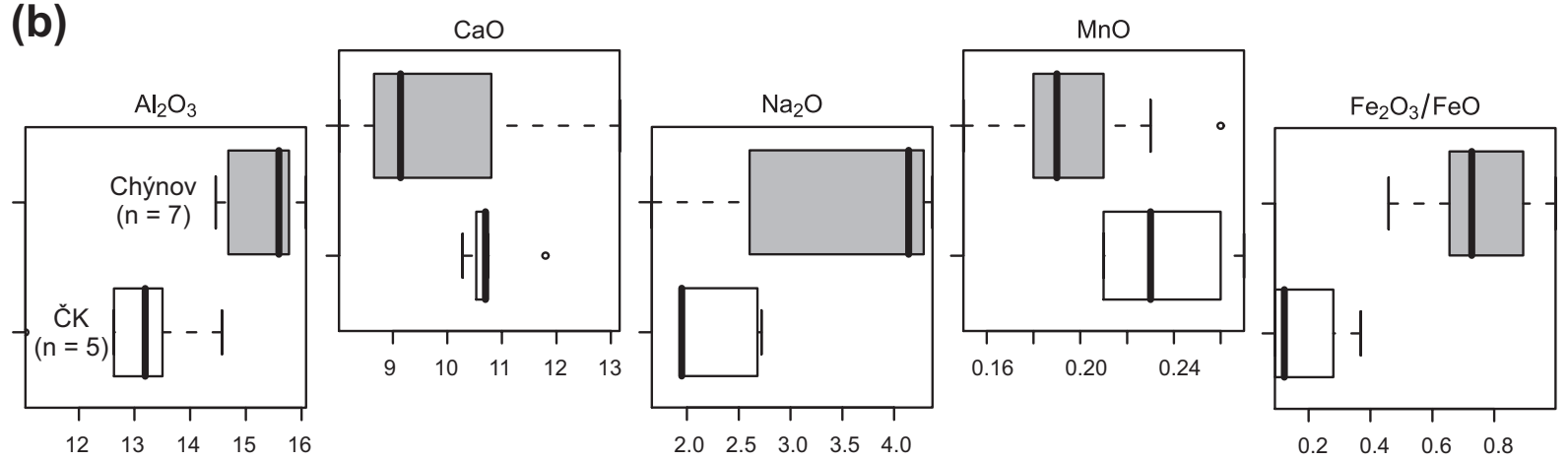

Fig. 7a - Binary plots of MgO versus major- and minor elements for the studied metabasites. b - Box plots for selected oxides comparing the newly obtained data for the amphibolites from the Chýnov (top) and Český Krumlov (ČK, bottom) varied units (wt. \%; see also Tab. 3). 
Table 4a Trace-element whole-rock geochemical analyses for the amphibolites from the Chýnov Varied Unit (ppm)

\begin{tabular}{|c|c|c|c|c|c|c|c|}
\hline Sample & A-1 & A-2 & A-3 & A-4 & A-5 & A-6 & A-7 \\
\hline \multirow[t]{2}{*}{ Locality } & Obrataň & Chýnov & Chýnov & Chýnov & Chýnov & Kladr. h. & Šimpach \\
\hline & amphibolite & amphibolite & amphibolite & amphibolite & amphibolite & amphibolite & amphibolite \\
\hline $\mathrm{Rb}$ & 4.0 & 3.2 & 7.8 & 7.6 & 8.2 & 13.9 & 6.9 \\
\hline $\mathrm{Sr}$ & 242.1 & 238.4 & 466.8 & 469.9 & 223.3 & 135.4 & 167.1 \\
\hline $\mathrm{Ba}$ & 21.3 & 52.5 & 210.4 & 173.9 & 81.4 & 52.6 & 20.6 \\
\hline $\mathrm{Cr}$ & 349 & 21 & 116 & 123 & 48 & 144 & 630 \\
\hline $\mathrm{Ni}$ & 159 & 13 & 65 & 72 & 17 & 62 & 267 \\
\hline $\mathrm{Co}$ & 48.8 & 42.7 & 40.1 & 43.2 & 44.5 & 47.7 & 55.0 \\
\hline $\mathrm{Sc}$ & 40 & 38 & 25 & 26 & 41 & 43 & 34 \\
\hline $\mathrm{V}$ & 347 & 515 & 308 & 336 & 482 & 329 & 217 \\
\hline Mo & 0.2 & 0.8 & 0.8 & 0.8 & 0.4 & 0.2 & 0.1 \\
\hline $\mathrm{Pb}$ & 0.4 & 0.6 & 1.3 & 1.2 & 0.3 & 0.9 & 0.6 \\
\hline $\mathrm{Zn}$ & 12 & 40 & 29 & 26 & 48 & 26 & 14 \\
\hline $\mathrm{Ga}$ & 18.9 & 23.8 & 22.8 & 25.0 & 23.9 & 20.8 & 14.8 \\
\hline $\mathrm{Zr}$ & 104 & 260 & 252 & 260 & 239 & 89 & 29 \\
\hline Hf & 3.0 & 6.9 & 6.4 & 6.7 & 6.4 & 2.7 & 1.1 \\
\hline $\mathrm{Nb}$ & 4.9 & 11.2 & 40.7 & 42.9 & 10.7 & 4.2 & $<0.5$ \\
\hline $\mathrm{Ta}$ & 0.4 & 0.8 & 2.7 & 2.9 & 0.8 & 0.3 & $<0.1$ \\
\hline Th & 0.5 & 1.6 & 2.7 & 3.3 & 1.1 & 2.2 & $<0.1$ \\
\hline $\mathrm{U}$ & 0.2 & 0.6 & 1.1 & 1.0 & 0.9 & 0.5 & 0.1 \\
\hline $\mathrm{La}$ & 5.30 & 18.30 & 29.60 & 30.70 & 14.00 & 11.60 & 0.80 \\
\hline $\mathrm{Ce}$ & 15.90 & 46.00 & 71.10 & 74.80 & 39.10 & 24.50 & 2.70 \\
\hline $\operatorname{Pr}$ & 2.52 & 6.61 & 9.13 & 9.56 & 5.78 & 3.31 & 0.57 \\
\hline $\mathrm{Sm}$ & 3.80 & 8.40 & 7.60 & 8.10 & 7.80 & 3.60 & 1.50 \\
\hline $\mathrm{Eu}$ & 1.30 & 2.90 & 2.62 & 2.59 & 2.58 & 1.41 & 0.69 \\
\hline $\mathrm{Gd}$ & 4.54 & 8.85 & 6.53 & 7.00 & 8.90 & 4.67 & 2.53 \\
\hline $\mathrm{Tb}$ & 0.90 & 1.71 & 1.01 & 1.04 & 1.56 & 0.87 & 0.47 \\
\hline Dy & 5.42 & 10.21 & 5.36 & 5.75 & 9.40 & 5.45 & 3.41 \\
\hline Ho & 1.10 & 1.98 & 0.95 & 0.95 & 1.87 & 1.10 & 0.71 \\
\hline $\mathrm{Er}$ & 3.13 & 5.77 & 2.46 & 2.46 & 5.17 & 3.17 & 2.00 \\
\hline $\mathrm{Tm}$ & 0.45 & 0.85 & 0.33 & 0.33 & 0.77 & 0.47 & 0.31 \\
\hline $\mathrm{Yb}$ & 2.95 & 5.03 & 1.79 & 2.19 & 4.72 & 2.87 & 1.84 \\
\hline $\mathrm{Lu}$ & 0.41 & 0.80 & 0.26 & 0.28 & 0.68 & 0.45 & 0.27 \\
\hline $\mathrm{Y}$ & 29.8 & 55.6 & 25.0 & 26.7 & 50.7 & 30.2 & 18.5 \\
\hline $\mathrm{Eu} / \mathrm{Eu}^{*}$ & 0.96 & 1.03 & 1.14 & 1.05 & 0.95 & 1.05 & 1.08 \\
\hline $\mathrm{La}_{\mathrm{N}} / \mathrm{Yb}_{\mathrm{N}}$ & 1.21 & 2.45 & 11.15 & 9.45 & 2.00 & 2.72 & 0.29 \\
\hline $\mathrm{La}_{\mathrm{N}} / \mathrm{Sm}_{\mathrm{N}}$ & 0.88 & 1.37 & 2.45 & 2.38 & 1.13 & 2.03 & 0.34 \\
\hline Sum REE & 59.72 & 148.51 & 176.94 & 186.55 & 130.33 & 77.97 & 21.70 \\
\hline
\end{tabular}

unit they belong to, also have high V (217-519 ppm) and Sc (25-46 ppm) contents. While Sc fails to define any trend with $\mathrm{MgO}$ (not shown), the $\mathrm{MgO}-\mathrm{V}$ plot displays a reasonable negative correlation. The Chýnov dataset tends to have higher $\mathrm{Cr}$ and $\mathrm{Ni}$, and lower $\mathrm{V}$ with $\mathrm{Sc}$, than the Český Krumlov samples (Fig. 8b).

The high-field strength elements (HFSE) show much more complex relationships. The MgO-Th plot features an inflection at $\mathrm{MgO} \sim 6-7 \mathrm{wt} . \%$; $\mathrm{Zr}$ and, to a large extent, $\mathrm{Nb}$ define negative trends for all but the most $\mathrm{MgO}$-poor samples.

The $\mathrm{MgO}-\mathrm{Sr}$ graph is considerably scattered. The plots with $\Sigma$ REE and $\mathrm{Ce}_{\mathrm{N}} / \mathrm{Yb}_{\mathrm{N}}$ (the latter parameter chosen instead of $\mathrm{La}_{\mathrm{N}} / \mathrm{Yb}_{\mathrm{N}}$ due to the dubious quality of La determinations in the data set of Patočka 1991) clearly represent mixtures of two trends, a positive one, 
(a)
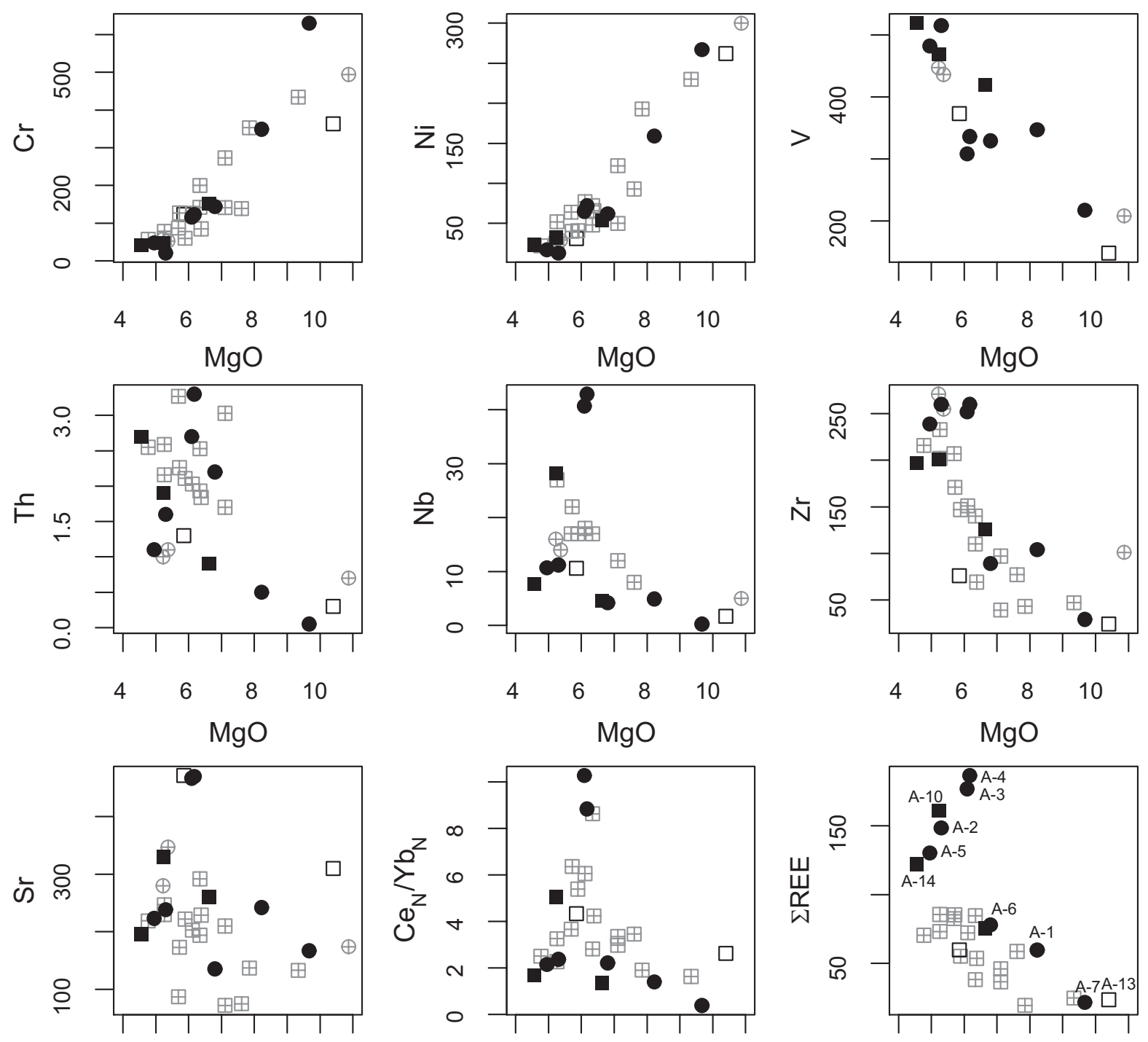

$$
4 \quad 6 \underset{M g}{8} 10
$$

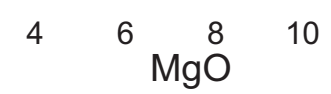

$$
\begin{array}{llrr}
4 & 6 & 8 & 10 \\
& & \\
& & &
\end{array}
$$

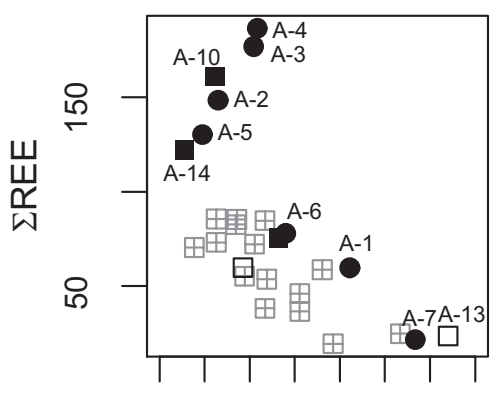

(b)
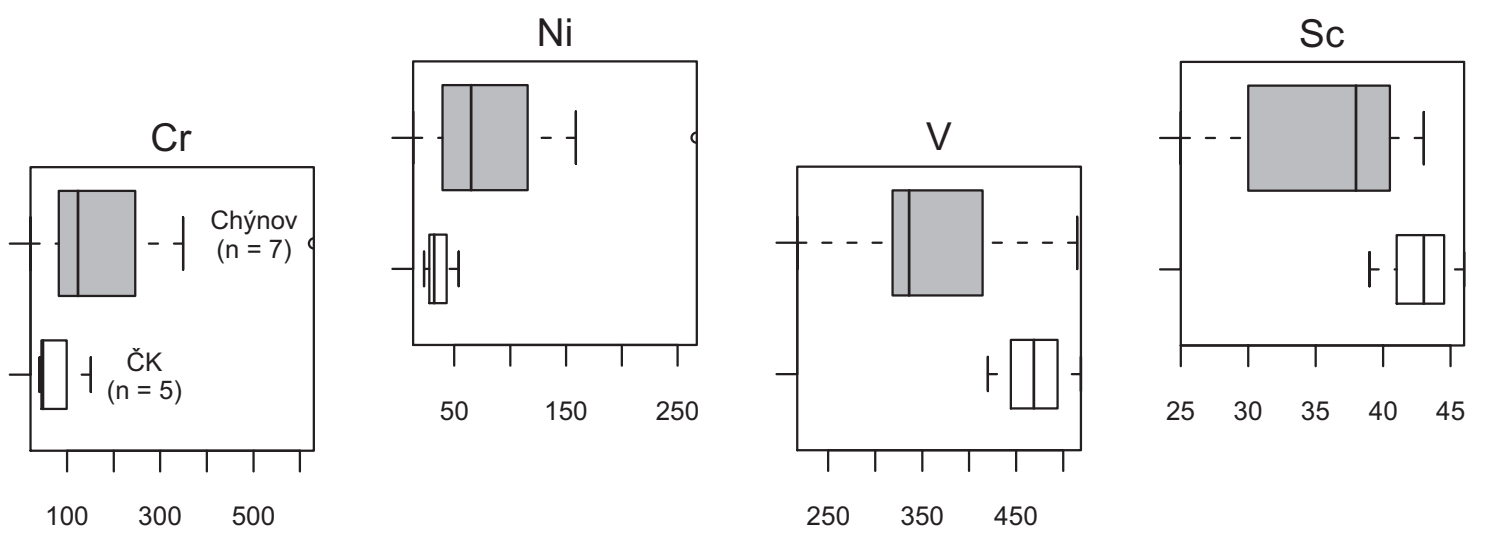

Fig. 8a - Binary diagrams of $\mathrm{MgO}$ versus selected trace elements (ppm). $\mathrm{The}_{\mathrm{Ne}} / \mathrm{Yb}_{\mathrm{N}}$ is the ratio of chondrite-normalized values (Boynton 1984). b - Box plots for selected transition metal concentrations comparing the Chýnov and Český Krumlov (ČK) amphibolites (ppm; Tab. 4). 
Table 4b Trace-element whole-rock geochemical analyses for the metabasic rocks from the Český Krumlov Varied Unit (ppm)

\begin{tabular}{|c|c|c|c|c|c|}
\hline Sample & A-10 & A-14 & A-15 & A-12 & A-13 \\
\hline \multirow[t]{2}{*}{ Locality } & $\begin{array}{c}\text { Zlatá } \\
\text { Koruna }\end{array}$ & Lazec & Vyšný & $\begin{array}{c}\text { Plánský } \\
\text { Kopec }\end{array}$ & Světlík \\
\hline & A & A & A & G & $\mathrm{D}$ \\
\hline $\mathrm{Rb}$ & 10.2 & 15.1 & 8.0 & 28.9 & 4.1 \\
\hline $\mathrm{Sr}$ & 329.8 & 195.6 & 259.9 & 471.4 & 310.0 \\
\hline $\mathrm{Ba}$ & 231.0 & 86.2 & 76.7 & 163.6 & 60.0 \\
\hline Cs & 0.5 & 0.1 & 0.2 & 1.9 & 0.3 \\
\hline $\mathrm{Cr}$ & 48 & 41 & 151 & 123 & 363 \\
\hline $\mathrm{Ni}$ & 32 & 23 & 54 & 31 & 262 \\
\hline $\mathrm{Co}$ & 52.0 & 50.7 & 49.5 & 44.3 & 66.0 \\
\hline $\mathrm{Sc}$ & 39 & 43 & 46 & 27 & 21 \\
\hline V & 469 & 519 & 420 & 373 & 148 \\
\hline Mo & 0.9 & 0.4 & 0.5 & 0.3 & 0.3 \\
\hline $\mathrm{Cu}$ & 86 & 25 & 45 & 22 & 64 \\
\hline $\mathrm{Pb}$ & 1.0 & 0.3 & 0.5 & 4.6 & 0.4 \\
\hline $\mathrm{Zn}$ & 39 & 39 & 14 & 24 & 4 \\
\hline $\mathrm{Ga}$ & 23.2 & 23.6 & 19.1 & 22.2 & 16.2 \\
\hline $\mathrm{Zr}$ & 201 & 197 & 126 & 76 & 24 \\
\hline Hf & 5.9 & 5.7 & 3.9 & 2.1 & 0.7 \\
\hline $\mathrm{Nb}$ & 28.2 & 7.7 & 4.5 & 10.6 & 1.7 \\
\hline $\mathrm{Ta}$ & 1.9 & 0.5 & 0.3 & 0.7 & 0.1 \\
\hline Th & 1.9 & 2.7 & 0.9 & 1.3 & 0.3 \\
\hline $\mathrm{U}$ & 0.9 & 0.7 & 0.3 & 0.4 & 0.1 \\
\hline $\mathrm{La}$ & 24.20 & 13.90 & 6.90 & 9.10 & 2.90 \\
\hline $\mathrm{Ce}$ & 57.60 & 34.50 & 19.40 & 21.60 & 7.30 \\
\hline $\operatorname{Pr}$ & 7.70 & 5.07 & 2.98 & 2.81 & 1.01 \\
\hline $\mathrm{Nd}$ & 34.10 & 25.40 & 15.20 & 12.50 & 5.00 \\
\hline $\mathrm{Sm}$ & 8.00 & 6.80 & 4.60 & 2.90 & 1.30 \\
\hline $\mathrm{Eu}$ & 3.02 & 2.13 & 1.69 & 1.08 & 0.60 \\
\hline $\mathrm{Gd}$ & 8.26 & 8.35 & 5.60 & 2.75 & 1.55 \\
\hline $\mathrm{Tb}$ & 1.25 & 1.60 & 1.15 & 0.49 & 0.26 \\
\hline Dy & 7.74 & 9.98 & 7.18 & 2.99 & 1.58 \\
\hline Но & 1.37 & 1.94 & 1.38 & 0.51 & 0.30 \\
\hline Er & 3.78 & 5.74 & 4.25 & 1.41 & 0.82 \\
\hline $\operatorname{Tm}$ & 0.50 & 0.85 & 0.62 & 0.19 & 0.10 \\
\hline $\mathrm{Yb}$ & 2.96 & 5.28 & 3.74 & 1.29 & 0.72 \\
\hline $\mathrm{Lu}$ & 0.41 & 0.75 & 0.57 & 0.18 & 0.10 \\
\hline Y & 37.5 & 56.9 & 39.9 & 14.8 & 8.2 \\
\hline $\mathrm{Eu} / \mathrm{Eu}^{*}$ & 1.14 & 0.86 & 1.02 & 1.17 & 1.29 \\
\hline $\mathrm{La}_{\mathrm{N}} / \mathrm{Yb}_{\mathrm{N}}$ & 5.51 & 1.77 & 1.24 & 4.76 & 2.72 \\
\hline $\mathrm{La}_{\mathrm{N}} / \mathrm{Sm}_{\mathrm{N}}$ & 1.90 & 1.29 & 0.94 & 1.97 & 1.40 \\
\hline Sum REE & 160.89 & 122.29 & 75.26 & 59.80 & 23.54 \\
\hline
\end{tabular}

$\mathrm{A}=$ amphibolite, $\mathrm{G}=$ metagabbro, $\mathrm{D}=$ metadolerite

restricted only to some of the less magnesian samples $(\mathrm{MgO}<6$ wt. \%) and negative for the rest of the dataset covering the whole $\mathrm{MgO}$ spectrum.
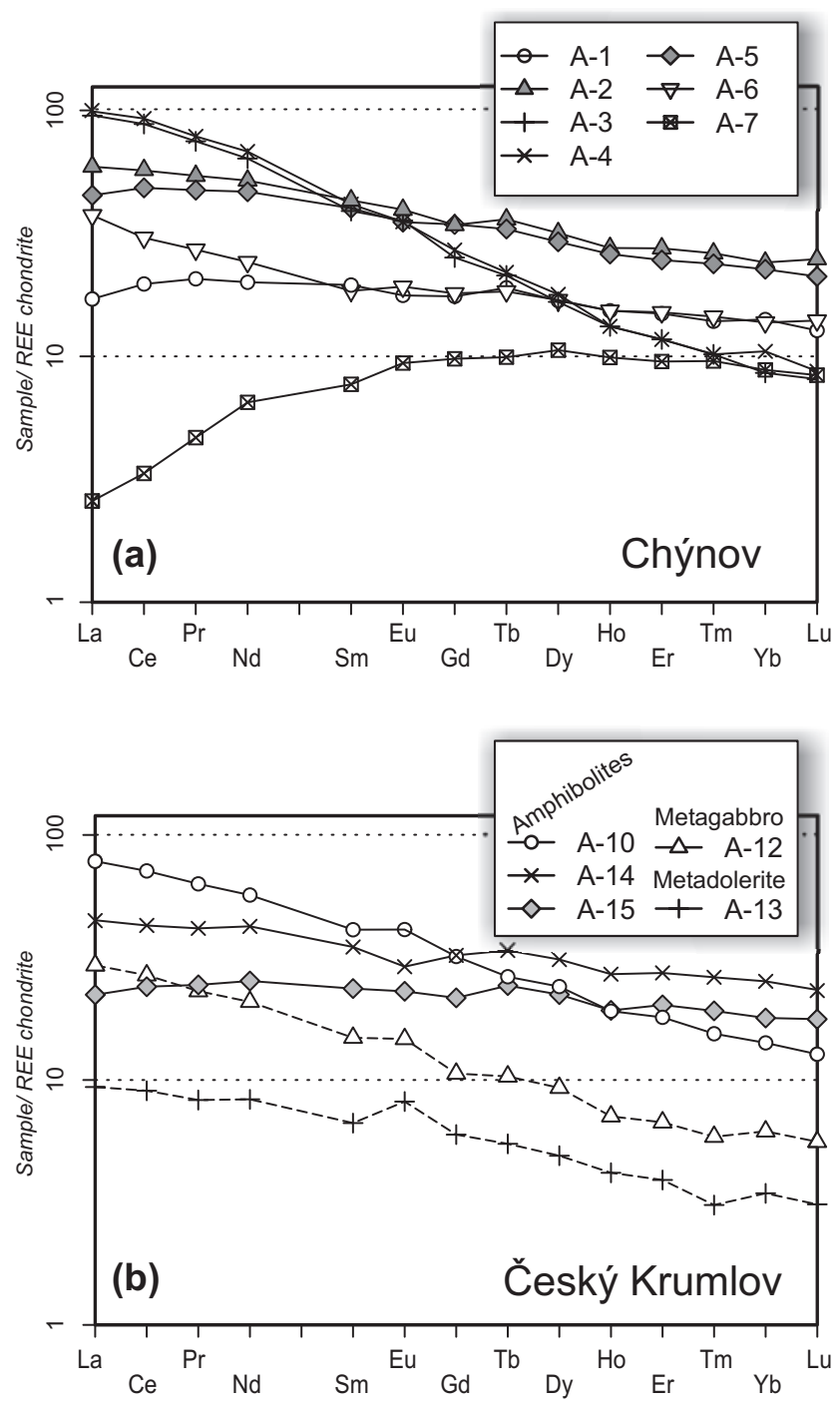

Fig. 9 Chondrite-normalized (Boynton 1984) REE patterns for the metabasic rocks from the Chýnov and Český Krumlov Varied units.

The chondrite-normalized (Boynton 1984) REE patterns for the Chýnov set are very variable (Fig. 9a), with total REE concentrations ranging between 59.7 and $186.6 \mathrm{ppm}$. The most primitive is the pattern for sample A-7, which shows strong LREE depletion (La only $2.6 \times$ chondritic value) relative to MREE and HREE (about $10 \times$ chondrite, $\left.\mathrm{La}_{\mathrm{N}} / \mathrm{Yb}_{\mathrm{N}}=0.29\right)($ Fig. 9a). This pattern resembles normal Mid-Ocean Ridge Basalts (NMORB). The other patterns show variable enrichments of LREE over HREE. For samples A-1, A-6, A-2 and A-5 profiles are all relatively flat $\left(\mathrm{La}_{\mathrm{N}} / \mathrm{Yb}_{\mathrm{N}}=1.21-9.45\right)$, with the total concentrations lower for the former two ( 2 REE 59.7 and $78.0 \mathrm{ppm}$ ) than for the latter two amphibolites ( $\mathrm{REE}$ 148.5 and $130.3 \mathrm{ppm}$ ). The patterns for the remaining alkaline samples A-3 and A-4 are steep, starting at about $100 \times$ chondritic value and dropping sharply with 

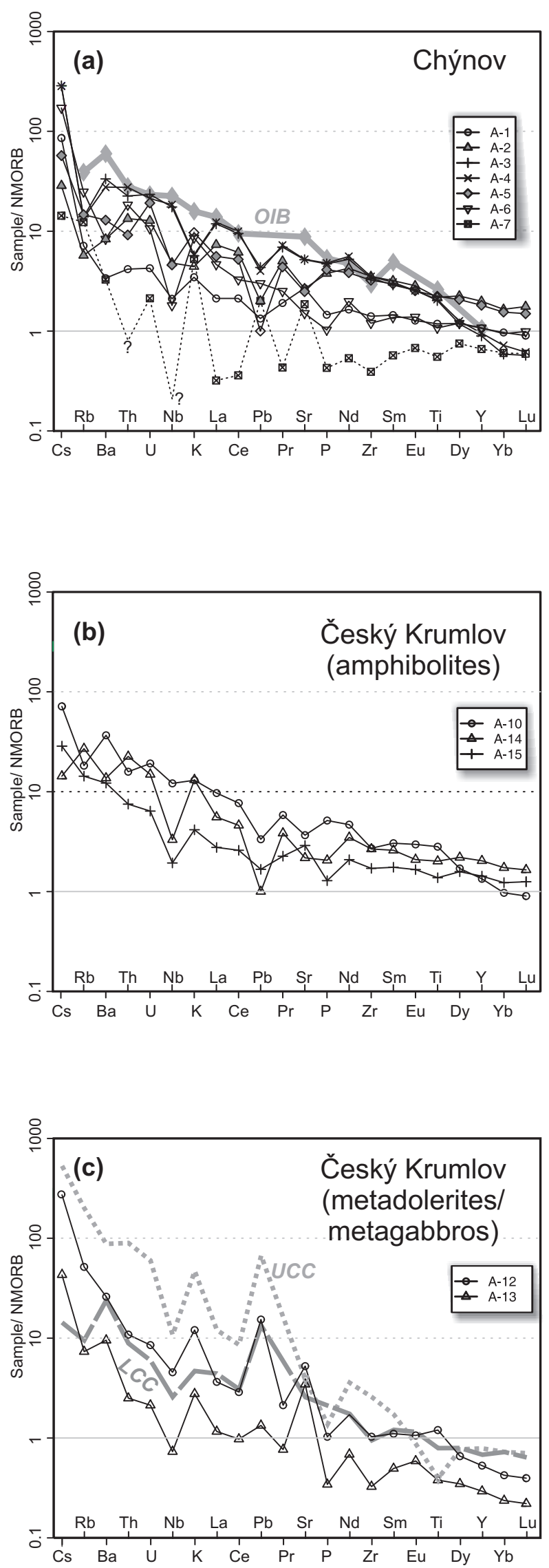

an increasing atomic number to less than $9\left(\mathrm{La}_{\mathrm{N}} / \mathrm{Yb}_{\mathrm{N}}=\right.$ 9.45-11.15, $\Sigma$ REE = 176.9-186.6). The Eu anomaly is absent or nearly so in all analysed amphibolites of the Chýnov set $\left(\mathrm{Eu} / \mathrm{Eu}^{*}=1.14-0.95\right)$.

The REE distribution for amphibolites from the Český Krumlov area (Fig. 9b) resembles the previous group, except for the magnitude of the Eu anomaly, which tends to be more variable. The most primitive seems the pattern for sample A-15 $\left(\mathrm{La}_{\mathrm{N}} / \mathrm{Yb}_{\mathrm{N}}=1.2, \Sigma \mathrm{REE}=75.3, \mathrm{Eu} / \mathrm{Eu}^{*}=\right.$ $1.02)$, followed by A-14 $\left(\mathrm{La}_{\mathrm{N}} / \mathrm{Yb}_{\mathrm{N}}=1.8, \Sigma \mathrm{REE}=122.3\right.$, $\left.\mathrm{Eu} / \mathrm{Eu}^{*}=0.86\right)$. The most fractionated is amphibolite A-10 from Zlatá Koruna $\left(\mathrm{La}_{\mathrm{N}} / \mathrm{Yb}_{\mathrm{N}}=5.5, \Sigma \mathrm{REE}=160.9\right.$, $\left.\mathrm{Eu} / \mathrm{Eu}^{*}=1.14\right)$.

Both metadolerite and metagabbro are characterised by relatively low total REE contents (23.5-59.8), notable enrichment of LREE over HREE $\left(\mathrm{La}_{\mathrm{N}} / \mathrm{Yb}_{\mathrm{N}}=2.72-4.76\right)$ and marked positive Eu anomalies $\left(\mathrm{Eu} / \mathrm{Eu}^{*}=1.17-1.29\right)$.

The NMORB normalized (Sun and McDonough 1989) spider plots of the studied metabasic rocks are all variably enriched in LILE (Fig. 10). The most primitive seems to be sample A-7, with a striking zigzag pattern apparently caused by some element mobility. The presumably less mobile REE (La, Ce, Pr, Nd, Sm, Eu, Dy, $\mathrm{Yb}$ and $\mathrm{Lu}$ ) plus some HFSE (Zr, Ti, Y, with Th and $\mathrm{Nb}$ ) remain relatively low, some even below their detection limits (indicated by question marks in Fig. 10a). By contrast P (0.32-0.75 $\times$ NMORB), and the hydrous fluid mobile elements ( $\mathrm{Cs}, \mathrm{Rb}, \mathrm{Ba}, \mathrm{U}, \mathrm{K}, \mathrm{Pb}, \mathrm{Sr})$ are several times enriched. Sample A-1 shows a relatively flat pattern enriched only in $\mathrm{Rb}$ and $\mathrm{Cs}$; there is a slight depletion in $\mathrm{Nb}$ and $\mathrm{Pb}$ as well as weak enrichment in Sr. Overall, the pattern resembles EMORB (e.g., Wilson 1989; Pearce 1996). Amphibolite A-6 shows a striking Nb depletion and less marked $\mathrm{P}$ and $\mathrm{Zr}$ impoverishment. The least compatible elements are of similar concentration to the preceding sample, but the contents of alkalis with Th and $\mathrm{U}$ are significantly higher.

Amphibolites A-2 and A-5 contain generally comparable contents of the incompatible elements up to $\mathrm{K}$, but the contents of the remaining elements are significantly higher than in A-6. The samples are characterised by marked $\mathrm{Nb}, \mathrm{Pb}$ and $\mathrm{Sr}$ troughs. Finally, the patterns of alkali metabasalts A-3 and A-4 closely follow each other. Their normalized trace-element concentrations are overall relatively high, with exception of the HREE that •

Fig. 10 The NMORB-normalized (Sun and McDonough 1989) spider plots for the analysed metabasites. a - Amphibolites from the Chýnov area, question marks indicate values below detection limit in sample A-7. The pattern labelled OIB is from an average composition of Ocean Island Basalts (Sun et al. 1980). b - amphibolites from the Český Krumlov Varied Unit. c - metadolerite and metagabbro from the Světlík area. For assessment of the possible crustal contamination, shown are average crustal compositions after Taylor and McLennan (1995): UCC = Upper Continental Crust, $\mathrm{LCC}=$ Lower Continental Crust. 
show a marked depletion. Troughs for $\mathrm{Rb}, \mathrm{K}$ and $\mathrm{Pb}$ are also characteristic. Apart from these three elements, the trace-element distribution for amphibolites A-3 and A-4 strongly resembles the average compositions of Ocean Island Basalts (OIB), as determined by Sun et al. (1980).

In the Český Krumlov amphibolite dataset (Fig. 10b), the lowest NMORB-normalized trace-element contents are those of sample A-15, starting at around 14 $\times$ NMORB $(\mathrm{Rb})$ and dropping to nearly 1 for $\mathrm{Lu}$. The pattern displays slight negative anomalies for $\mathrm{Nb}, \mathrm{Pb}$ and P. Sample A-14 is similar, but its total trace-element contents are markedly higher and the $\mathrm{Nb}, \mathrm{Pb}, \mathrm{Sr}$ and $\mathrm{P}$ troughs deeper. The pattern of sample A-10 resembles closely the Chýnov alkali types A-3 and A-4; only the negative $\mathrm{K}$ anomaly is lacking.

Overall, the spider plots for the metadolerite and metagabbro are similar to each other (Fig. 10c), but sample A-12 has significantly higher total trace-element concentrations. The patterns are characterised by increasing positive anomalies of $\mathrm{K}, \mathrm{Pb}$ and $\mathrm{Sr}$, reflecting, together with the REE distribution characterised by an emerging positive Eu anomaly (Fig. 9b), an accumulation of mainly plagioclase and biotite.

\section{Radiogenic isotopes ( $\mathrm{Sr}$ and $\mathrm{Nd}$ )}

The $\mathrm{Nd}$ isotopic analyses for the studied metabasic rocks are given in Tab. 5, together with initial $\varepsilon_{N d}^{i}$ age-corrected for 350 and $500 \mathrm{Ma}$ (Fig. 11a). Also presented are singlestage $\mathrm{Nd}$ model ages calculated relative to Depleted Mantle ( $\mathrm{T}_{N d}^{D M}$ : Liew and Hofmann 1988) (Fig. 11b).

\subsection{Chýnov Varied Unit}

The single-stage Depleted-mantle Nd model ages show considerable variation. The tholeiitic samples A-1, A-2, A-5 and A-7 yield Cambro-Ordovician model ages $\left(\mathrm{T}_{N d}^{D M}=0.43-0.50 \mathrm{Ga}\right)$ (Fig. 11b). The model ages for the alkaline amphibolites A-3 and A-4 are much higher $\left(\mathrm{T}_{N d}^{D M}=0.83 \mathrm{Ga}\right)$, but the Kladrubská hora sample A-6 has the highest model age $\left(\mathrm{T}_{N d}^{D M}=1.47 \mathrm{Ga}\right)$. As the derivation of these basic rocks from a source other than Earth's mantle is considered impossible, at least at reasonable degrees of partial melting, the single-stage Nd should provide a maximum constraint upon the age of their intrusion (see also Fig. 11b).

Assuming, for the sake of discussion, an identical protolith age of $c .500 \mathrm{Ma}, \varepsilon_{N d}^{500}$ values can be calculated. These are all positive, corresponding to mantle-derived melts, but their range is large (Tab. 5; Fig. 11). The most primitive (i.e., most radiogenic) is $\mathrm{Nd}$ in the tholeiitic samples: A-5 (Pod Pacovou horou quarry, $\varepsilon_{N d}^{500}=+9.1$ ), A-7 (Šimpach, $\varepsilon_{N d}^{500}=+9.0$ ), followed by amphibolites A-1

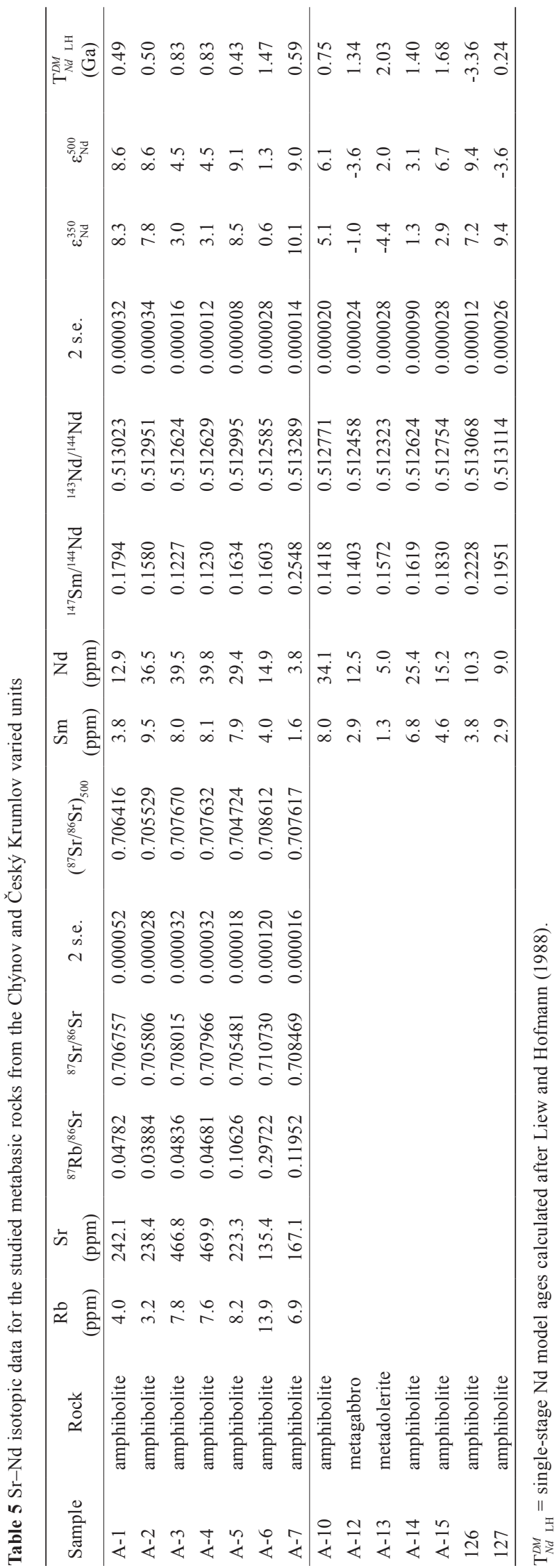



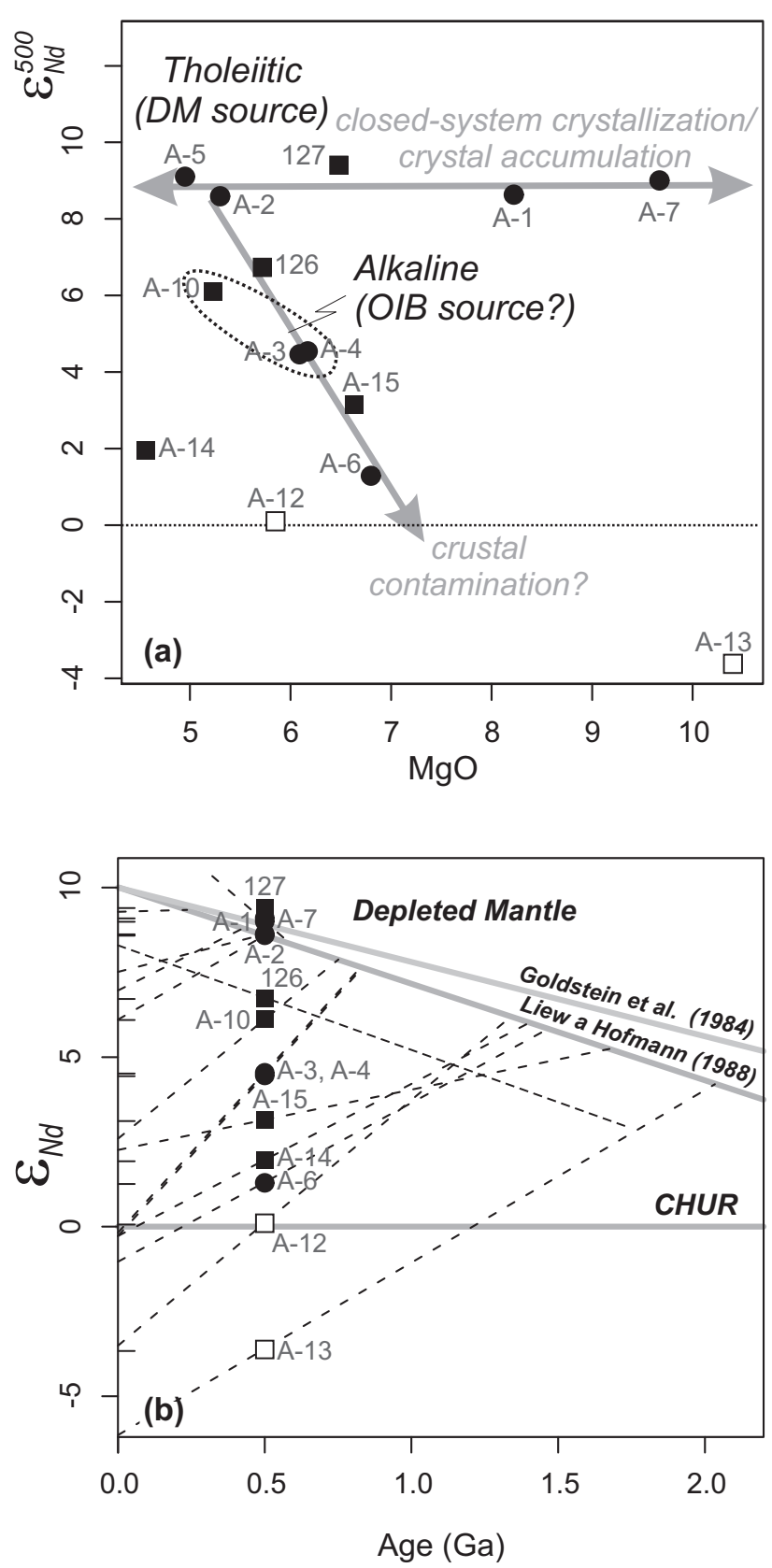

Fig. 11a - Binary plot of $\mathrm{MgO}$ vs. $\varepsilon_{\mathrm{Nd}}^{500}$ for the studied metabasites. The field for alkaline amphibolites is outlined. Also drawn are vectors showing tentative evolution by closed-system fractionation (fractional crystallization or crystal accumulation) and crustal contamination. b - Single-stage Nd development diagram showing ranges of $\varepsilon_{\mathrm{Nd}}^{500}$ values and Depleted-mantle model ages in the amphibolites and metadolerite with metagabbro from the southern Bohemian Varied Group (Chýnov and Český Krumlov areas). DM = Depleted Mantle evolution lines after Goldstein et al. (1984) and Liew and Hofmann (1988).

and A-2 (Obrataň and Pod Pacovou horou quarry, $\varepsilon_{N d}^{500}=$ $+8.6)$. The least radiogenic are the alkaline amphibolites with steep REE patterns from the last mentioned locality $\left(\mathrm{A}-3\right.$ and $\left.\mathrm{A}-4, \varepsilon_{N d}^{500}=+4.5\right)$ and, in particular, the Kladrub- ská hora sample $\left(\mathrm{A}-6, \varepsilon_{N d}^{500}=+1.3\right)$. At least part of this variation, shown graphically in Fig. 11a, may be due to crustal contamination as discussed below.

Initial ratios of $\mathrm{Sr}$ for amphibolites from the Chýnov area calculated for the same age cover a wide range (0.7044-0.7083). Again, the most primitive is the tholeiitic sample A-5 (Pod Pacovou horou, ${ }^{87} \mathrm{Sr} /{ }^{86} \mathrm{Sr}_{500}=$ 0.7047), while sample A-6 (Kladrubská hora) has the highest ratio (0.7086), and the $\mathrm{Sr}$ isotopic signature of samples A-7 (Šimpach, 0.7076) and A-3 (Pod Pacovou horou, 0.7077$)$ are also relatively radiogenic.

\section{2. Český Krumlov area}

In the Český Krumlov area, only Nd isotopic compositions have been determined. The $\varepsilon_{N d}^{500}$ values are almost as variable as in the Chýnov Varied Unit. The most radiogenic amphibolite is sample 127 from Hořice $\left(\varepsilon_{N d}^{500}=\right.$ +9.4 ), followed in turn by 126 (Lískovec, $\varepsilon_{N d}^{500}=+6.7$ ), A-10 (Zlatá Koruna, $\varepsilon_{N d}^{500}=+6.1, \mathrm{~T}_{N d}^{D M}=0.75 \mathrm{Ga}$ ), A-15 (Vyšný, $\varepsilon_{N d}^{500}=+3.1, \mathrm{~T}_{N d}^{D M}=1.68 \mathrm{Ga}$ ) and A-14 (Lazec, $\left.\varepsilon_{N d}^{500}=+2.0, \mathrm{~T}_{N d}^{D M}=1.40 \mathrm{Ga}\right)$.

The metadolerite and metagabbro have significantly less radiogenic $\mathrm{Nd}$ isotopic signatures (A-12 from Kovářov: $\varepsilon_{N d}^{500}=+0.1, \mathrm{~T}_{N d}^{D M}=1.34 \mathrm{Ga} ; \mathrm{A}-13$ from Světlík: $\varepsilon_{N d}^{500}=-3.6$, $\mathrm{T}_{N d}^{D M}=2.03 \mathrm{Ga}$ ). The $\mathrm{Nd}$ isotopic composition thus precludes a closed-system crystallization of these rocks from Depleted Mantle derived melts in Palaeozoic times.

\section{Discussion}

\subsection{Metamorphic development}

\subsubsection{Conditions of metamorphism}

The studied amphibolites lack relict minerals from either their igneous protoliths or of metamorphic stages other than the amphibolite-facies metamorphism, e.g. greenschist or granulite facies. Hence it is likely that the amphibolites formed by an intense, single-stage metamorphic recrystallization of the original igneous protolith and the rocks have not recorded any further metamorphic history.

Ilmenite in Chýnov samples A-2, A-3, A-4 contains about 15 vol. \% of unmixed hematite in minute lenticular particles. This, together with slightly elevated $\mathrm{Fe}_{2} \mathrm{O}_{3}$ content in host ilmenite, indicates somewhat increased $\mathrm{O}_{2}$ fugacity in these particular amphibolites. Note that comparable increased oxygen fugacity was not observed in samples from the Český Krumlov area, which contain ilmenite free of hematite, either in solid solution or unmixed. The future will tell whether this is not simply because of sampling bias, as the current data set is rather 
small. Still it is clear that the oxygen fugacity was not uniform throughout the south Bohemian Varied Group (see also Němec 1998) and the amphibolites represent a heterogeneous set in this respect.

\subsubsection{Geochemical changes due to meta- morphism}

The sampling strategy was chosen in order to minimize the effects of Variscan metamorphism upon the whole-rock geochemical signature. Relatively large and fresh blocks of metabasic rocks were utilized, showing little effects of alteration and subsequent low-grade metamorphic overprint or deformation. Unlike their counterparts enclosed in gneisses, amphibolites forming layers in marbles are much less susceptible to an increase in LILE contents, as these elements are not present in significant amounts in the host carbonate rocks. The only LILE enriched should be clearly Sr and Ba (Němec 1999). The samples associated with carbonates were obtained from the quarries Pod Pacovou horou (A-2 to A-5) and Vyšný (A-15). None of these analyses showed $\mathrm{Sr}$ or Ba spikes in NMORB-normalized spider plots, and thus even these elements seem to have been relatively immobile geochemically in our data set.

On the other hand, effects of LILE influx from the host rocks are apparent in some of the remaining samples, but nowhere are they as severe as in the otherwise most depleted sample A-7 (Fig. 10a). Its radiogenic Nd and $\mathrm{Sr}$ isotopic ratios also demonstrate some Sr mobility and relatively conservative $\mathrm{Nd}$ behaviour.

Even though some scatter in the binary plots involving alkalis and perhaps Sr (Figs 7a and 8a), together with minor irregularities in the spider plots for the studied metabasites (Fig. 10), undoubtedly reflects metamorphic mobility of the elements with low ionic potential, no systematic changes were observed by plotting these against $\mathrm{H}_{2} \mathrm{O}^{+}$as an index of alteration (Pearce 1996). Overall, the contents of volatile components remain relatively low, bearing witness that the superimposed alteration of the whole-rock geochemical signature was relatively minor in all the studied samples.

\subsection{Petrogenesis and age of the basaltic/ gabbroic protoliths}

\subsubsection{Nature of the volcanism}

Amphibolites in the Pacovská hora quarry are accompanied by impure silicate marbles and calc-silicate rocks carrying assemblages with epidote, Ti-andradite and minor magnetite, which independently point to increased oxygen activity. Comparably high and variable degree of Fe oxidation shows that at least part of the amphibolites represents original subaerial (or submarine) effusions. It is possible that they represent an association of a relatively shallow (shelf?) sea, an idea supported by the occurrence of the strongly oxidized association Ti-andradite-epidote-magnetite in carbonate-metabasic rocks and, in particular, Mn-rich garnet gneisses at the margin of the amphibolite layer in the Pod Pacovou horou quarry (Vrána 1992). This model is in line with previous work - for instance, the shallow sea/lagoon reef sedimentation for the Český Krumlov Varied Unit has been suggested already by Jenček and Vajner (1968), Kříbek et al. (1997) and Drábek et al. (1999).

It is thus probable that the protolith of some basaltic rocks in the Chýnov area experienced an incipient oxidation early in the depositional history of the local sequence, a feature which survived the amphibolite-facies regional metamorphism. Unfortunately, geological and petrological evidence does not permit safe distinction of alternatives such as basaltic lava flows, shallow sills or somewhat later dykes, as structural transposition imposed by deformation obliterated the original structural relations.

On the other hand, the amphibolites of the Český Krumlov Varied Unit are not so oxidised, possibly because of their direct association with graphite schists; the organic matter present in the latter could have caused reduction in the adjacent rock complexes. In contrast, in the Chýnov area the association between amphibolites and the graphite-bearing rocks is not so intimate.

\subsubsection{Relationship between amphibolites and metadolerites/metagabbros in the Český Krumlov area}

The Světlík orthogneiss was interpreted as an old basement, on which the Český Krumlov Varied Unit was deposited (Wendt et al. 1993). It is possible that the basic (doleritic/gabbroic) dykes cutting the Světlík orthogneiss represent former conduits of basaltic melts, which formed syn-sedimentary extrusive sheets or shallow sills in the overlying Český Krumlov Varied Unit. Alternatively, the basic dykes may be older than, or unrelated to, the amphibolites in the Varied Unit.

The whole-rock geochemical signature of the metadolerites/metagabbros seems to imply that they contain a sizeable admixture of cumulus crystals (dominated by plagioclase) derived from fairly basic magmas. Their rather unradiogenic $\mathrm{Nd}$ isotopic composition precludes closed-system crystallization of melts derived from Depleted Mantle in Palaeozoic times. The metadolerites/ metagabbros must be significantly older, have originated from a less depleted mantle domain, and/or they received a significant crustal component - either in the form of country-rock assimilation or by mixing with crustally-de- 
rived magmas. As both the samples seem to be cumulates to some extent, their relatively low $\mathrm{SiO}_{2}$ accompanied by high $\mathrm{MgO}, \mathrm{Cr}, \mathrm{Ni}$ and $m g \#$ does not seem to reflect the original composition of the magma they have crystallized from. If true, the parental melt could have been more acid (even tonalitic) and thus could have been, largely or fully, intracrustally derived, spanning from partial melting of pre-existing metabasic lower crust (Rapp et al. 1991; Wolf and Wyllie 1994).

Without a larger dataset for the metadolerites/metagabbros, the nature of their parental magma remains enigmatic. Even so, a genetic link between the studied metadolerites/metagabbros and amphibolites of the Český Krumlov Varied Unit seems unlikely. The substantial differences in the $\mathrm{Nd}$ isotopic compositions (metagabbro with metadolerite are much less radiogenic) rule out their connection via closed-system fractional crystallization/ accumulation (Fig. 11).

\subsubsection{Age of the Varied Group in southern Bohemia}

The age and petrogenesis of the Varied Group of the Moldanubian Zone in southern Bohemia are still a matter of passionate discussion. The great majority of the earlier authors have championed its Proterozoic sedimentation (see Chaloupský 1978). The reports on finds of microfossils from the Český Krumlov Varied Unit (Konzalová 1981; Pacltová and Štemprok 1994), taken by some as an evidence for the Early Palaeozoic age of the Varied Group, are still far from being generally accepted.

An attempt to date the Varied Group carbonates in Austria directly using Sr isotopes was made by Frank et al. (1990) and the idea was recently resurrected by Procházka (2007). The authors inferred a Proterozoic age, arguing that the measured ${ }^{87} \mathrm{Sr} /{ }^{86} \mathrm{Sr}$ ratios were too low for the carbonates to have precipitated from Phanerozoic seawater.

However the Sr stratigraphy underwent a speedy development over the past two decades and the existence of some potential pitfalls became obvious. The first are diagenetic changes to the $\mathrm{Sr}$ isotopic ratios. As the whole-rock samples are the most sensitive to such effects, analyses of carefully picked fresh fossils of the genera that tend to recrystallize only a little in course of the diagenesis (conodonts, brachiopods,...) are preferred. Moreover, additional checks, such as CL screening, are employed. Other potential problems in the Moldanubian carbonates seem to be the presence of possible clastic/ volcanic admixture and the danger of $\mathrm{Sr}$ mobility during high-grade Variscan metamorphism. Most important objection is though that in such a dismembered metamorphic terrain, there is no guarantee that the basin, in which the carbonates were deposited, communicated with the world's ocean reservoir. Obviously, in an isolated basin, the $\mathrm{Sr}$ isotopic composition could have been completely unconstrainable, depending simply on the balance of fluxes from individual sources and the nature of the eroded material (McArthur 1998; Prokoph and Veizer 1999; Veizer et al. 1999).

Last but not least, with a few exceptions (Houzar and Novák 2002), there is no convincing evidence that the individual Moldanubian domains in both Austria and Czech Republic with relatively abundant amphibolites and carbonates indeed belong to a single "Varied Unit" in a lithostratigraphic sense (see also Finger et al. 2007 and references therein). The fact that the situation may be rather complex even within a single metamorphic terrain has been indicated by the recent study of metabasites from the Raabs Unit, Lower Austria, which yielded a range of compositions and LA ICP-MS zircon ages (Mesoproterozoic-Silurian, Mayer et al. 2005; 2007).

The age of the south Bohemian Varied Group may be deduced from the garnet-rich kinzigitic gneisses from Ktiš in the Lhenice Graben, which contain a complex population of zircons dated by the $\mathrm{Pb}-\mathrm{Pb}$ evaporation method at 1.6-2.0 Ga and $549 \pm 5 \mathrm{Ma}$ (Wendt 1989; Fiala et al. 1995). The younger population puts an upper constraint upon the maximum age of sedimentation.

However, the only direct age determination from the south Bohemian Varied Group (Český Krumlov Varied Unit) to date remains the Re-Os dating of molybdenite scattered in carbonate from the Bližná graphite mine (495 \pm 2 Ma: Drábek and Stein 2003). Moreover, betafite from the same deposit has a primitive $\mathrm{Nd}$ isotopic composition $\left(\varepsilon_{N d}^{450}=+7.9\right)$, and a high $\mathrm{Sm} / \mathrm{Nd}$ ratio, permitting a calculation of the $\mathrm{Nd}$ model age $\left(\mathrm{T}_{N d}^{D M}=0.53 \mathrm{Ga}\right)$ with considerable precision. This datum can be interpreted as providing additional, maximum constraint for the age of Mo-Nb-Th-REE mineralization in Bližná (Drábek et al. 1999).

The dating by Drábek and Stein (2003) confirms the earlier $\mathrm{Nd}$ isotopic data for amphibolites of the south Bohemian Varied Group, presented in the preliminary report by Janoušek et al. (1997) and, in a more detail, in the current work. The $\mathrm{Nd}$ isotopic compositions for tholeiitic amphibolites A-1, A-2, A-5 and A-7 from the Chýnov area as well as the sample 136 from Český Krumlov Varied Unit does document their Early Palaeozoic magmatic age.

\subsubsection{Presumed mantle sources and further development of the basaltic melts}

The primitive Nd isotopic signature and EMORB-like chemistry of many of the tholeiitic samples indicate basaltic protolith derivation from a strongly depleted mantle source. The other tholeiitic samples probably suffered 
some crustal contamination, as indicated by the binary plots of independent geochemical parameters versus initial epsilon $\mathrm{Nd}$ values (e.g., Fig. 11a).

Also the alkaline amphibolites (A-3, A-4: Chýnov, A-10: Český Krumlov area) contain much less radiogenic $\mathrm{Nd}$ than the uncontaminated tholeiitic metabasalts do. Their less radiogenic initial $\mathrm{Nd}$ isotopic compositions (and thus more "crustal" signature) can be explained by: (1) older (Proterozoic) age, (2) origin by partial melting of a less depleted mantle domain, (3) contamination by a material rich in $\mathrm{MgO}, \mathrm{CaO}, \mathrm{REE}, \mathrm{Sr}$, and with crustal $\mathrm{Sr}-\mathrm{Nd}$ isotopic signature.

However, the alkaline basalts are different from their tholeiitic counterparts in a number of additional parameters - they show steep REE patterns, and contain high concentrations of HFSE, especially $\mathrm{Nb}, \mathrm{Ta}, \mathrm{Zr}$ and $\mathrm{P}$. The NMORB-normalized spider plots resemble OIB but cannot be explained by contamination with mature continental crust (see e.g. the lack of negative $\mathrm{Nb}$ anomaly). The patterns feature a marked depletion in HREE indicating a derivation from a garnet-bearing source. All these observations point in the same direction, namely that the alkaline types originated by relatively deep, low-degree partial melting of a less depleted, OIB-like asthenospheric mantle source.

At the same time, there is an intimate association between the tholeiitic and alkaline basalts, which may indicate that the two suites intruded at about the same time. Further evidence that the alkaline volcanism could have been contemporaneous with the deposition of the Český Krumlov Varied Unit is the presence of volcano-detritic component enriched in REE, $\mathrm{Y}, \mathrm{Th}, \mathrm{Nb}$ a $\mathrm{Zr}$ in the mineralized carbonates of the Bližná mine (Drábek et al. 1999).

\subsubsection{Geotectonic setting}

The geotectonic setting for the basic volcanism in the Bohemian part of the Moldanubian Zone has been explained in various ways, in accord with its likely temporal and geochemical heterogeneity as well as improvement in the analytical facilities with time. Matějovská (1987) assumed for her Fe-rich tholeiites (TMORB) from the region between Jemnice and Náměšt' (SW Moravia) an origin in a rift-related basin that formed at the margin of the Moldanubian Unit. Patočka (1991) interpreted tholeiites from the Český Krumlov Varied Unit as relics of an accretionary wedge built up close to a subduction zone as a melange of volcanic-arc derived sediments (now paragneisses), ocean floor and ocean island basalts (later metamorphosed to amphibolites).

Most recently, Moravcová (1999) attempted to decipher the original geotectonic setting of the Moldanubian metabasic rocks. She interpreted most of them as TMORB and offered a wide palette of possible geotec- tonic contexts (initial volcanic arc, volcanic arc with back-arc basin, rift-related or collisional tectonics). This is hardly surprising, given that a significant interpretative power was ascribed to highly mobile LILE. Moreover, the dataset was heterogeneous, blending, without petrologic control, analyses for samples from the whole Moldanubian Zone in Bohemian Massif, carried out by different methods in different laboratories.

Indeed, the great majority of the Moldanubian amphibolites seem to be tholeiitic, with a distinct MORB affinity (Němec 1995; 1998) even though their chemistry has been, to some extent, modified by Variscan metamorphism (Němec 1999). Basic rocks probably linked to active subduction (Fe-rich gabbros) are only subordinate (Němec 1996b).

The NMORB-normalized spider plots (Fig. 10) already highlighted some geochemical features, which have a bearing on the probable geotectonic setting of the studied metabasic rocks from the Chýnov and Český Krumlov varied units. Most of the tholeiitic amphibolites resemble EMORB, with the rarer alkaline types being close to OIB. The only sample with clear NMORB affinity, albeit modified by ?olivine accumulation and LILE contamination, is A-7. The likely geotectonic setting was further constrained using several discrimination plots, summarized in Fig. 12.

The $10 \times \mathrm{MnO}-\mathrm{TiO}_{2}-10 \times \mathrm{P}_{2} \mathrm{O}_{5}$ diagram (Fig. 12a) of Mullen (1983) utilizes relatively immobile minor elements Mn, Ti and P. The studied samples show an affinity to MORB, straddling the boundaries of the adjacent tholeiitic domains and entering the OIA field (occupied by the alkaline samples with the highest phosphorus contents). Amphibolite A-7 is, together with metadolerite A-13, shifted towards the $\mathrm{MnO}$ apex, probably as a result of crystal accumulation.

Similar conclusions can be drawn using the ternary diagram $\mathrm{Zr} / 4-2 \times \mathrm{Nb}-\mathrm{Y}$ of Meschede (1986) (Fig. 12b). The samples span the compositions of mid-ocean ridge basalts (the prevalent tholeiitic metabasalts), as well as within-plate tholeiitic and alkaline basalts (alkaline samples, in particular A-3 and A-4).

Two diagrams defined by Pearce and Cann (1973) were also plotted. On a $\mathrm{Zr}-\mathrm{Ti} / 100-3 \times \mathrm{Y}$ ternary diagram (Fig. 12c), the samples mainly occupy fields $D$ (Within Plate Basalts, WPB) and B, shared by the MORB, Island Arc Basalts (CAB) and Low-K Tholeiites (IAT). This distribution resembles strongly basaltic rocks associated with attenuated lithosphere (see e.g. fig. 9 in Pearce 1996 and discussion in the text). Better discrimination of the MORB from the arc-related rock types is achieved in the $\mathrm{Zr}-\mathrm{Ti} / 100-\mathrm{Sr} / 2$ triangular plot (Fig. 12d), in which the overwhelming majority of the samples fall into the MORB domain. Only three samples, A-7, metagabbro A-12 and metadolerite A-13, form a linear array towards 


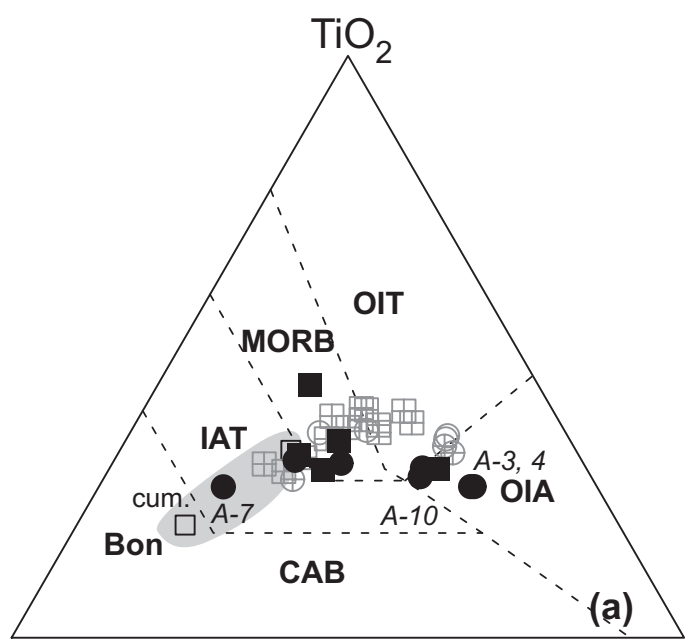

$10 \times \mathrm{MnO}$

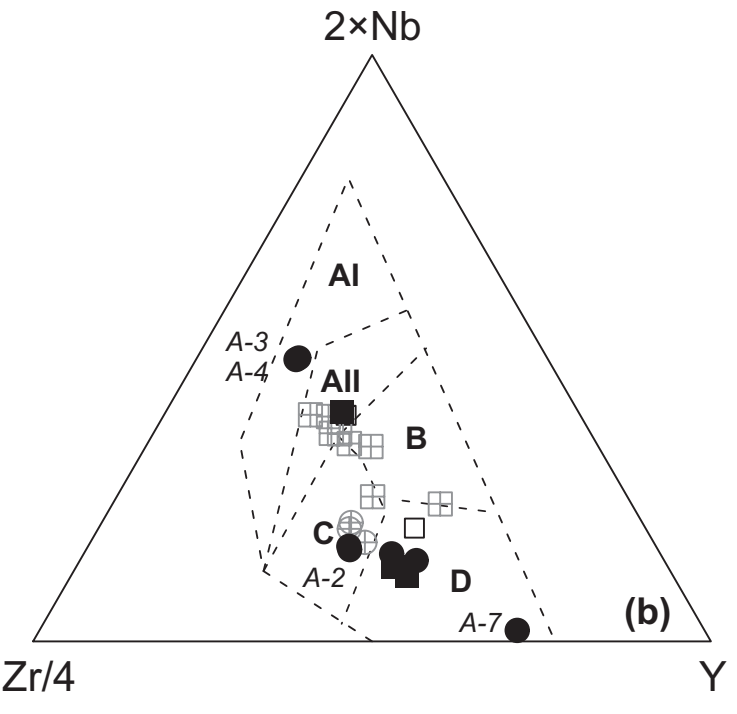

$\mathrm{Ti} / 100$
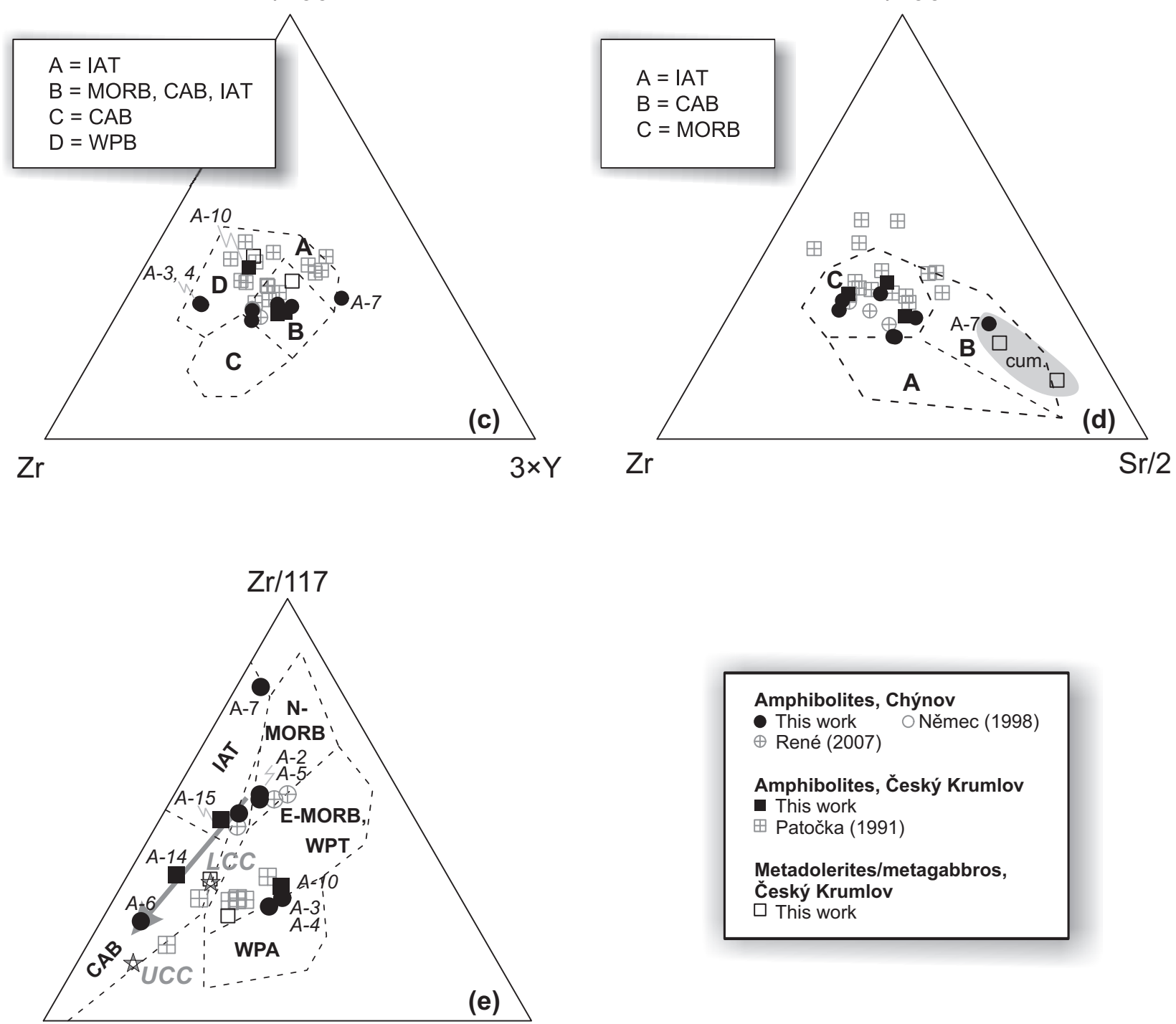

Amphibolites, Chýnov

- This work ONěmec (1998)

$\oplus$ René (2007)

Amphibolites, Český Krumlov

- This work

$\boxplus$ Patočka (1991)

Metadolerites/metagabbros,

Český Krumlov

$\square$ This work 
the $\mathrm{Sr}$ apex, probably reflecting the presence of cumulus plagioclase.

Finally, in a $\mathrm{Th}-\mathrm{Zr} / 117-\mathrm{Nb} / 16$ ternary diagram (Fig. 12e) (Wood 1980), the alkaline types occupy the field of within-plate alkaline basalts (WPA). However the remaining analyses do not plot solely in the NMORB field, but also cross the boundary into the adjacent $\mathrm{CAB}$ domain, spreading towards the average upper crustal composition as determined by Taylor and McLennan (1995). This, together with the $\mathrm{Nd}$ isotopic data array formed by the same amphibolites A-15, A-14 and A- 6 (Fig. 11b) is taken as an evidence for crustal contamination (see also Floyd et al. 1996; Pearce 1996).

Apart from enrichment in Th, this crustal contamination is also documented by the development of the negative $\mathrm{Nb}$, and much less apparent, $\mathrm{P}$ and $\mathrm{Ti}$ anomalies in the NMORB-normalized spider plots (cf. the UCC pattern in Fig. 10c, representing average composition of the Upper Crust after Taylor and McLennan 1995). Apart from likely metamorphic modification, the lack of a positive $\mathrm{Pb}$ peak can be due to the fact that the contaminant could have been a relatively young (Neoproterozoic/Early Palaeozoic?) crust. On the other hand, it clearly cannot represent the common Moldanubian paragneisses (as they have too low $\mathrm{MgO}, \mathrm{CaO}$ and $\Sigma \mathrm{REE}$ ) pure carbonates or seawater (too low $\Sigma$ REE). One viable possibility could be the agency of $\mathrm{CO}_{2}$-rich fluids, presumably related to diagenesis of the associated carbonate rocks (see also Vrána 1992).

Taken together, despite some minor differences between the Chýnov and Český Krumlov Varied units, the studied amphibolites seem to represent a single association, dominated by EMORB tholeiitic basalts. These were derived by relatively shallow melting of a strongly depleted mantle source in Early Palaeozoic times. The whole-rock and $\mathrm{Nd}$ isotopic signature in several cases reflects contamination by upper continental crust, prob-

\section{↔}

Fig. 12 Geotectonic discrimination diagrams for the metabasites from the south Bohemian Varied Group. a -Triangular plot with apices $10 \times \mathrm{MnO}-\mathrm{TiO}_{2}-10 \times \mathrm{P}_{2} \mathrm{O}_{5}$ proposed by Mullen (1983). Abbreviations used represent the following geotectonic settings: CAB: Calc-Alkaline Basalts, IAT: Island Arc Tholeiites, MORB: Mid-Ocean Ridge Basalts, OIA: Ocean Island Andesites, OIT: Ocean Island Tholeiites. b - Triangular diagram $\mathrm{Zr} / 4-2 \times \mathrm{Nb}-\mathrm{Y}$ of Meschede (1986). AI-AII: Within-Plate Alkaline Basalts, AII-C: Within-Plate Tholeiites, B: Ptype Mid-Ocean Ridge Basalts, D: N-type Mid-Ocean Ridge Basalts, C-D: Volcanic Arc Basalts. c-d - Set of two ternary plots, Zr - Ti/100 $-3 \times \mathrm{Y}$ and $\mathrm{Zr}-\mathrm{Ti} / 100-\mathrm{Sr} / 2$, proposed by Pearce and Cann (1973). Following abbreviations are used: IAT: Low-K Tholeiites, MORB: Ocean Floor Basalts, CAB: Island Arc Basalts, WPB: Within Plate Basalts. e - Triangular diagram with apices $\mathrm{Th}, \mathrm{Zr} / 117$ and $\mathrm{Nb} / 16$ after Wood (1980). IAT: Island-arc Tholeiites, CAB: Calc-alkaline Basalts, N-MORB: N-type Mid-ocean Ridge Basalts, E-MORB: E-type Midocean Ridge Basalts, WPT: Within-plate Tholeiites, WPA: Alkaline Within-plate Basalts. Shown are average crustal compositions after Taylor and McLennan (1995): UCC $=$ Upper Continental Crust, LCC = Lower Continental Crust. ably during the ascent of the parental melts towards the surface.

A minority of the samples are alkaline, showing a clear OIB affinity and requiring a genesis by low degrees of partial melting of a deeper, garnet-bearing asthenospheric mantle source. Their age remains unconstrained but the intimate association with the tholeiites and the presence of an exotic carbonatite-like volcano-sedimentary component in some of the Moldanubian carbonates (Drábek et al. 1999; Houzar and Novák 2002) suggest that they may be also Early Palaeozoic.

In general, as stressed by Pearce (1996) in his excellent review, the problem remains the discrimination of basalts from environments transitional between those of the principal three end-members (MORB, WPB and VAB). Thus even for the studied tholeiitic, EMORB-like amphibolites of the Varied Group, an emplacement in essentially intracrustal and not a truly oceanic setting is to be assumed. This idea is supported by the association between prevalent MORB-like and subordinate WPB-like basalts (nicely documented for instance by the position in the $\mathrm{Zr}-\mathrm{Ti} / 100-3 \times \mathrm{Y}$ ternary), relatively significant role for mature crustal contamination needed to explain the geochemical signature some of the samples as well as intimate association with shallow-water (lagoonal) sediments.

The most likely tectonic setting of the volcanism was thus attenuated lithosphere, subjected to a significant extension and initial stages of rifting, marking the onset of the fragmentation of the northern Gondwana margin producing the Armorica Terrane Assemblage (e.g., Franke 2000; Floyd et al. 2000). The minor OIB component preserved in the form of alkali basalts as well as some contribution to the EMOR-like basaltic magmas was probably contributed by a mantle plume. Such a plume was indeed thought to have assisted the early stages of the fragmentation of Gondwana and the accompanying extensive igneous activity (e.g., Crowley et al. 2000; Floyd et al. 2000).

\section{Conclusions}

(1) Amphibolites from the Chýnov and Český Krumlov units of the Moldanubian Zone in south Bohemia are dominated by amphibolite-facies mineral assemblages of plagioclase and hornblendes with $\mathrm{Si} \sim 6.5 \mathrm{apfu}, \mathrm{Mg} /(\mathrm{Mg}+\mathrm{Fe}) \sim 0.5$ and $(\mathrm{Na}+\mathrm{K})_{\mathrm{A}}$ $\sim 0.5 \mathrm{apfu}$, straddling mainly the fields of edenite, pargasite, ferropargasite, and magnesiohornblende, ferrohornblende and ferrotschermakite. Garnet and clinopyroxene are subordinate and occur in a few samples only. No relics of previous greenschist- or granulite-facies mineral assemblages have been 
observed, most likely as a result of a relatively simple metamorphic history.

(2) The petrology indicates a rather close correlation of the Chýnov and Český Krumlov units. The similarities include the presence of dolomite in carbonate bodies, association with graphite schists, occurrence of rocks with marialitic scapolite, locally also of Ti-andradite ( \pm magnetite, epidote) assemblages and thin layers of Mn-rich garnet-quartz rocks.

(3) However, there is a major difference in the oxidation state of the studied amphibolites. Most Chýnov samples have $\mathrm{Fe}_{2} \mathrm{O}_{3} / \mathrm{FeO}=0.70$ to 1.00 . Accessory ilmenite containing c. 15 vol. \% of unmixed hematite and appreciable hematite in solid solution are typical. It is probable that the protolith of basaltic rocks experienced an incipient oxidation early in the depositional history of the local sequence. At least some of the parental basalts were probably effusive, either subaerial or subaqueous.

(4) The Český Krumlov amphibolites have typically $\mathrm{Fe}_{2} \mathrm{O}_{3} / \mathrm{FeO} \leq 0.4$, ilmenite is free of unmixed hematite and contains little hematite in solid solution. They show much closer association with graphite schists, in which the organic matter could have been responsible for reduction of the adjacent rock units.

(5) The dataset is dominated by EMORB-like tholeiitic metabasalts derived by melting of a strongly depleted mantle source in Early Palaeozoic times $\left(\varepsilon_{N d}^{500}=+8.6\right.$ to $\left.+9.4 ; \mathrm{T}_{N d}^{D M}=0.43-0.50 \mathrm{Ga}\right)$. The rather unradiogenic $\mathrm{Nd}$ isotopic composition of several of the samples reflects probably contamination by upper continental crust $\left(\varepsilon_{N d}^{500}=+3.1\right.$ to +1.3$)$. This is in line with gradual enrichment in Th, a significant negative $\mathrm{Nb}$, and lesser $\mathrm{P}$ and $\mathrm{Ti}$ anomalies on the NMORB-normalized multielement patterns for the more contaminated samples.

(6) The previously considered indications of Precambrian age of Moldanubian varied sequences in Austria, which were based on whole-rock $\mathrm{Sr}$ isotopic compositions of carbonates, are doubtful and not directly applicable to the Varied Group in south Bohemia. As shown in the current study, the $\mathrm{Nd}$ model ages for the least contaminated tholeiitic basalts in intimate association with reef/lagoonal carbonates argue for the Early Palaeozoic protolith age of the Chýnov and Český Krumlov units.

(7) Subordinate are alkaline metabasalts $(\mathrm{Nb} / \mathrm{Y}=0.7-1.6)$ with high total REE contents, steep chondrite-normalized REE patterns $\left(\mathrm{La}_{\mathrm{N}} / \mathrm{Yb}_{\mathrm{N}}=5.5-11\right)$ and high concentrations of HFSE, especially $\mathrm{Nb}, \mathrm{Ta}, \mathrm{Zr}$ and $\mathrm{P}$. Their NMORB-normalized spiderplots show a clear OIB affinity $\left(\varepsilon_{N d}^{500}=+4.5\right.$ to $\left.+6.1 ; \mathrm{T}_{N d}^{D M}=0.75-0.83 \mathrm{Ga}\right)$.

(8) Basic dykes cutting the Palaeoproterozoic Světlík orthogneiss are represented by amphibole metagab- bro, ophitic olivine metadolerite and porphyritic olivine-pyroxene metadolerite. These rocks show a rather unradiogenic $\mathrm{Nd}$ isotopic composition, which precludes closed-system crystallization of melts derived from depleted mantle source in Palaeozoic times $\left(\varepsilon_{N d}^{500}=+0.1\right.$ and $-3.6 ; \mathrm{T}_{N d}^{D M}=1.34$ and 2.03 $\mathrm{Ga})$. The nature of their parental magma remains enigmatic; however any genetic link between the studied metadolerites/metagabbros and amphibolites in the structurally overlying Český Krumlov Varied Unit seems unlikely.

(9) Geotectonic position, as inferred from commonly used geotectonic diagrams, is contrasting for the two amphibolite groups defined. The dominant tholeiitic amphibolites show (E)MORB chemistry, whereas the alkaline samples (A-3, A-4 and A-10) tend to plot into fields reserved for the within-plate basalts with OIB affinity. Tholeiites formed most likely by partial melting of a shallow, strongly depleted mantle source, with variable role for subsequent contamination by mature continental crust. Lowdegree partial melting of a garnet-bearing asthenospheric mantle is the most plausible scenario for the generation of the alkaline basalts.

(10) Taken together, the most likely tectonic setting of the volcanism was attenuated lithosphere, subjected to a significant extension leading to intracontinental rifting. This period marked the onset of the fragmentation of the northern Gondwana margin producing eventually the Armorica Terrane Assemblage. The minor OIB component preserved in the form of alkali basalts as well as some contribution to the EMOR-like basaltic magmas was probably added by a rising mantle plume.

Acknowledgments. We are indebted to J. Winchester for critical review and thorough language check, as well as J. Fiala for his constructive criticism. V. Kachlík is thanked for editorial handling. This research has been financed by the Czech Geological Survey internal project No. 3248.

\section{References}

BOYNTON WV (1984) Cosmochemistry of the rare earth elements: meteorite studies. In: Henderson P (ed) Rare Earth Element Geochemistry. Elsevier, Amsterdam, pp 63-114

Chaloupský J (1978) The Precambrian tectogenesis in the Bohemian Massif. Int J Earth Sci (Geol Rundsch ) 67: $72-90$

Crowley Q, Floyd P, Winchester J, Franke W, Holland J (2000) Early Palaeozoic rift-related magmatism in Va- 
riscan Europe; fragmentation of the Armorican terrane assemblage. Terra Nova 12: 171-180

DePaolo DJ (1981) Trace element and isotopic effects of combined wallrock assimilation and fractional crystallization. Earth Planet Sci Lett 53: 189-202

DePaolo DJ (1988) Neodymium Isotope Geochemistry. Springer Verlag, Berlin, pp 1-187

DickIN AP (1995) Radiogenic Isotope Geology. Cambridge University Press, Cambridge, pp 1-452

DrÁbeK M, SteIn H (2003) The age of formation of a marble in the Moldanubian Varied Group, Bohemian Massif, Czech Republic using Re-Os dating of molybdenite. In: Eliopoulos CJ, Spry P, Stein H, Beaudoin G (eds) Mineral Exploration and Sustainable Development. Millpress, Rotterdam, pp 973-976

Drábek M, Frýda J, Janoušek V, Šarbach M (1999) Regionally metamorphosed carbonatite-like marbles from the Varied Group, Moldanubian Unit, Bohemian Massif, Czech Republic and their Mo-Th-Nb-REE mineralization. In: Stanley CJ, Wall F, Williams CT, McDonald I, Prichard H (eds) Mineral Deposits: Processes to Processing. Proceedings of the Fifth Biennial SGA Meeting and the Tenth Quadrennial IAGOD Meeting, London, 22-25 August 1999. Balkema, Rotterdam, pp 635-638

FAURE G (2001) Origin of Igneous Rocks: The Isotopic Evidence. Springer Verlag, Berlin, pp 1-496

Fiala J, Fuchs G, Wendt JI (1995) Moldanubian Zone - Stratigraphy. In: Dallmeyer RD, Franke W, Weber K (eds) Pre-Permian Geology of Central and Eastern Europe. Springer Verlag, Berlin, pp 417-428

Finger F, Steyrer HP (1995) A tectonic model for the eastern Variscides: indications from a chemical study of amphibolites in the south-eastern Bohemian Massif. Geol Zbor Geol Carpathica 46: 137-150

Finger F, Gerdes A, Janoušek V, René M, Riegler G (2007) Resolving the Variscan evolution of the Moldanubian sector of the Bohemian Massif: the significance of the Bavarian and the Moravo-Moldanubian tectonometamorphic phases. J Geosci 52: 9-28

Floyd PA, Winchester JA (1975) Magma type and tectonic setting discrimination using immobile elements. Earth Planet Sci Lett 27: 211-218

Floyd PA, Winchester JA (1978) Identification and discrimination of altered and metamorphosed volcanic rocks using immobile elements. Chem Geol 21: 291-306

Floyd PA, Winchester JA, Ciesielczuk J, Lewandowska A, SzCZePański J, TuRniak K (1996) Geochemistry of early Palaeozoic amphibolites from the Orlica-Śnièżnik dome, Bohemian Massif: petrogenesis and palaeotectonic aspects. Geol Rundsch 85: 225-238

Floyd PA, Winchester JA, Seston R, Kryza R, Crowley QG (2000) Review of geochemical variation in lower Palaeozoic metabasites from the NE Bohemian Massif; intracratonic rifting and plume-ridge interaction.
In: Franke W, Haak V, Oncken O, Tanner D (eds) Orogenic Processes: Quantification and Modelling in the Variscan Fold Belt. Geol Soc London Spec Pub 179: pp 155-174

Floyd PA, Kryza R, Crowley QG, Winchester JA, Abdel WM (2002) Sleza Ophiolite; geochemical features and relationship to lower Palaeozoic rift magmatism in the Bohemian Massif. In: Winchester JA, Pharaoh TC, Verniers J (eds) Palaeozoic Amalgamation of Central Europe. Geol Soc London Spec Pub 201: pp 197-215

Franěk J, Schulmann K, Lexa O (2006) Kinematic and rheological model of exhumation of high pressure granulites in the Variscan orogenic root: example of the Blanský les granulite, Bohemian Massif, Czech Republic. Mineral Petrol 86: 253-276

Frank W, Hammer S, Popp F, Scharbert S, Thöni M (1990) Isotopengeologische Neuergebnisse zur Entwicklungsgeschichte der Böhmischen Masse. Österr Beitr Met Geoph 3: 185-228

FRANKE W (2000) The mid-European segment of the Variscides: tectonostratigraphic units, terrane boundaries and plate tectonic evolution. In: Franke W, Haak V, Oncken O, Tanner D (eds) Orogenic Processes: Quantification and Modelling in the Variscan Belt. Geol Soc London Spec Pub 179: pp 35-61

Friedl G, Finger F, Paquette JL, von Quadt A, McNaughtON NJ, Fletcher IR (2004) Pre-Variscan geological events in the Austrian part of the Bohemian Massif deduced from $\mathrm{U} / \mathrm{Pb}$ zircon ages. Int $\mathrm{J}$ Earth Sci (Geol Rundsch) 93: 802-823

Fritz H (1995) The Raabs Series: a probable Variscan suture in the SE Bohemian Massif. Jb Geol B-A 138: 639-653

Gebauer D, Friedl G (1994) A 1.38 Ga protolith age for the Dobra orthogneiss (Moldanubian zone of the southern Bohemian Massif, NE-Austria): evidence from ionmicroprobe (SHRIMP) dating of zircon. J Czech Geol Soc 39: 34-35

Goldstein SL, O`Nions RK, Hamilton PJ (1984) A Sm-Nd isotopic study of atmospheric dusts and particulates from major river systems. Earth Planet Sci Lett 70: 221-236

Harvey PK, AtKIN BP (1981) The rapid determination of $\mathrm{Rb}, \mathrm{Sr}$ and their ratios in geological materials by X-ray fluorescence spectrometry using a rhodium X-ray tube. Chem Geol 32: 155-165

HouZAR S, NovÁk M (2002) Marbles with carbonatite-like geochemical signature from variegated units of the Bohemian Massif, Czech Republic, and their geological significance. J Czech Geol Soc 47: 103-110

IrVINE TN, BARAGAR WRA (1971) A guide to the chemical classification of the common volcanic rocks. Can J Earth Sci 8: 523-548

JACOBSEN SB, Wasserburg GJ (1980) Sm-Nd isotopic evolution of chondrites. Earth Planet Sci Lett 50: 139-155 
JANOUŠEK V, VRÁNA S, VoKURKa K (1997) Strontium and neodymium isotopes in Moldanubian amphibolites from the surroundings of Chýnov (Southern Bohemia). Zpr geol Výzk v Roce 1996, 80-81 (In Czech)

JANOUŠEk V, Finger F, Roberts MP, Frýda J, Pin C, Dolejš D (2004) Deciphering petrogenesis of deeply buried granites: whole-rock geochemical constraints on the origin of largely undepleted felsic granulites from the Moldanubian Zone of the Bohemian Massif. Trans Roy Soc Edinb, Earth Sci 95: 141-159

JANOUŠEK V, ERBAN V, FARRow CM (2006a) Using the R language for graphical presentation and interpretation of compositional data in mineralogy: introducing the package GCDkit-Mineral. In: UseR! 2006 Book of Abstracts. Austrian Association for Statistical Computing (AASC) and Wirtschaftsuniversität Wien, Vienna, pp 84

JANOUŠEK V, FARROW CM, ERBAN V (2006b) Interpretation of whole-rock geochemical data in igneous geochemistry: introducing Geochemical Data Toolkit (GCDkit). J Petrol 47: 1255-1259

JENČEK V, VAJNER V (1968) Stratigraphy and relations of the groups in the Bohemian part of the Moldanubicum. Krystalinikum 6: 105-124

Jensen LS (1976) A New Cation Plot for Classifying Subalkalic Volcanic Rocks. Ontario Geol Surv Misc Paper 66: pp 1-22

KACHLíK V (1999) Relationship between Moldanubicum, the Kutná Hora Crystalline Unit and Bohemicum (Central Bohemia, Czech Republic): a result of polyphase Variscan nappe tectonics. J Czech Geol Soc 44: 201-291

KonZAlová M (1981) Some late Precambrian microfossils from the Bohemian Massif and their correlation. Precambr Res 15: $43-62$

Kröner A, Wendt I, Liew TC, Compston W, Todt W, Fiala J, VAŇKOVÁ V, VANĚK J (1988) U-Pb zircon and Sm-Nd model ages of high-grade Moldanubian metasediments, Bohemian Massif, Czechoslovakia. Contrib Mineral Petrol 99: 257-266

Kröner A, O`Brien PJ, Nemchin AA, Pidgeon RT (2000) Zircon ages for high pressure granulites from South Bohemia, Czech Republic, and their connection to Carboniferous high temperature processes. Contrib Mineral Petrol 138: 127-142

KŘíbeK B, Hladíková J, FrÝda J (1997) Scapolite- and anhydrite-bearing rocks from the Moldanubian Zone of the Bohemian Massif: metamorphosed exhalites and evaporates. J Czech Geol Soc 42: 62.

Leake BE, Wooley AR, Arps CES, Birch WD, Gilbert MC, Grice JD, Hawthorne FC, Kato A, Kisch HJ, KrivoviCheV VG, Linthout K, Laird J, Mandarino J, Maresch WV, Nickel EH, Rock NMS, Schumacher JC, Smith J C, Stephenson NCN, Whittaker EJW, Youzhi G (1997) Nomenclature of amphiboles: report of the Subcommittee on Amphiboles of the International Mineralogical
Association Commission on New Minerals and Mineral Names. Mineral Mag 61: 295-321

Le Bas MJ, Le Maitre RW, Streckeisen A, Zanettin B (1986) A chemical classification of volcanic rocks based on the total alkali-silica diagram. J Petrol 27: 745-750

Liew TC, Hofmann A W (1988) Precambrian crustal components, plutonic associations, plate environment of the Hercynian Fold Belt of Central Europe: indications from a Nd and Sr isotopic study. Contrib Mineral Petrol 98: 129-138

Lugmair GW, Marti K (1978) Lunar initial ${ }^{143} \mathrm{Nd} /{ }^{144} \mathrm{Nd}$ : differential evolution line of the lunar crust and mantle. Earth Planet Sci Lett 39: 349-357

MATĚJOvsKÁ O (1987) Fe-rich amphibolites wit tholeiitic affinity from the SE margin of the Bohemian Massif. Jb Geol B-A 130: 493-503

Mayer A, Gerdes A, Starijas B, Finger F (2005) Die Metabasitkörper des niederösterreichischen Moldanubikums: Geochemie und neue Zirkonalter. Mitt Österr mineral Gesell 151: 89

Mayer A, Gerdes A, Janoušek V, Erban V, Starijas B, FIngER F (2007) The metabasite bodies of the Moldanubian Zone in Lower Austria: geochemistry and zircon ages. In: Venera Z (ed) CzechTec 07. $5^{\text {th }}$ meeting of the Central European Tectonic Studies Group (CETeG) and $12^{\text {th }}$ Meeting of the Czech Tectonic Studies Group (ČTS). Czech Geological Survey, Prague, pp 56-57

McArthur JM (1998) Strontium Isotope Stratigraphy. In: Doyle P, Bennett MR (eds) Unlocking the Stratigraphical Record: Advances in Modern Stratigraphy. John Wiley a Sons, pp 221-241

Meschede M (1986) A method of discriminating between different types of mid-ocean ridge basalts and continental tholeiites with the $\mathrm{Nb}-\mathrm{Zr}-\mathrm{Y}$ diagram. Chem Geol 56: 207-218

MíkovÁ J, Denková P (2007) Modified chromatographic separation scheme for $\mathrm{Sr}$ and $\mathrm{Nd}$ isotope analysis in geological silicate samples. J Geosci 53: 221-226

Moravcová O (1999) Geochemistry of Moldanubian amphibolites (Bohemian Massif, Czech Republic). Krystalinikum 25: 83-103

Mullen ED (1983) $\mathrm{MnO} / \mathrm{TiO}_{2} / \mathrm{P}_{2} \mathrm{O}_{5}$ : a minor element discriminant for basaltic rocks of oceanic environments and its implications for petrogenesis. Earth Planet Sci Lett 62: 53-62

NĚMEC D (1994) Metamorphosed ferrogabbros of the WestMoravian Moldanubicum. Acta Mus Moraviae, Sci natur 79: $25-41$

NĚMEC D (1995) Regional distribution of chromium and nickel in Moldanubian MORB-derived amphibolites of the Bohemian-Moravian Heights. Scr Univ Masaryk brun, Geol 25: 21-35

NĚMEC D (1996a) Granulite facies metabasites in the Náměšt' granulite complex, western Moravia. Věst Čes geol úst 71: 277-284 
NĚMEC D (1996b) Metamorphosed Mg gabbros of the West Moravian Moldanubicum. Acta Mus Moraviae, Sci natur 81: 41-51

NĚMEC D (1997) High-Al amphibolites of the BohemianMoravian Heights. Acta Mus Moraviae, Sci natur 82: 63-72

NĚMEC D (1998) Highly mafic amphibolites in the Moldanubian Zone of the Bohemian-Moravian Heights (Českomoravská vrchovina). Acta Mus Moraviae, Sci natur 83: 59-71

NĚMEC D (1999) Chemical changes in Moldanubian amphibolites caused by regional metamorphism. Krystalinikum 25: 105-125

O'BRIEN PJ (2006) Type-locality granulites: high-pressure rocks formed at eclogite-facies conditions. Mineral Petrol 86: $161-175$

O'BRIEN PJ (2008) Challenges in high-pressure granulite metamorphism in the era of pseudosections: reaction textures, compositional zoning and tectonic interpretation with examples from the Bohemian Massif. J Metamorph Geol 26: 235-251

O'BRIEn PJ, RötZler J (2003) High-pressure granulites: formation, recovery of peak conditions and implications for tectonics. J Metamorph Geol 21: 3-20

Pacltová B, Štemprok M (1994) Silurian (Wenlockian) sporomorph in South Bohemian Moldanubicum. J Czech Geol Soc 39: 81-82

РАтос̌KA F (1987) The geochemistry of mafic metavolcanics: implications for the origin of the Devonian massive sulfide deposits at Zlaté Hory, Czechoslovakia. Miner Depos 22: 144-150

РАтос̌KA F (1991) Geochemistry and primary tectonic environment of the amphibolites from the Český Krumlov Varied Group (Bohemian Massif, Moldanubicum). Jb Geol B-A 134: 117-133

Patoč́a F, Kachlík V, Dostal J, Frána J (2003) Granitoid gneisses with relict orbicular metagranitoids from the Varied Group of the southern Bohemian Massif Moldanubicum: protolith derived from melting of Archaean crust? J Czech Geol Soc 48: 100-101

Pearce JA (1996) A user's guide to basalt discrimination diagrams. In: Wyman DA (ed) Trace Element Geochemistry of Volcanic Rocks: Applications for Massive Sulphide Exploration. Geol Assoc Canada, Short Course Notes 12: pp 79-113

Pearce JA, Cann JR (1973) Tectonic setting of basic volcanic rocks determined using trace element analyses. Earth Planet Sci Lett 19: 290-300

Pin C, Zalduegui JFS (1997) Sequential separation of light rare-earth elements, thorium and uranium by miniaturized extraction chromatography: Application to isotopic analyses of silicate rocks. Anal Chim Acta 339: 79-89

Pin C, Briot D, Bassin C, Poitrasson F (1994) Concomitant separation of strontium and samarium-neodymium for isotopic analysis in silicate samples, based on specific extraction chromatography. Anal Chim Acta 298: 209-217

ProchÁzKA V (2007) The composition of Moldanubian marbles - an important argument for a Precambrian age of the Varied Group. Sbor Jihočes Muz v Č. Budějovicích, Př́r Vědy 47: 27-38 (in Czech)

Prokoph A, Veizer J (1999) Trends, cycles and nonstationerities in isotope signals of Phanerozoic seawater. Chem Geol 161: 225-240

Racek M, Ští́sská P, Pitra P, Schulmann K, Lexa O (2006) Metamorphic record of burial and exhumation of orogenic lower and middle crust: a new tectonothermal model for the Drosendorf window (Bohemian Massif, Austria). Mineral Petrol 86: 221-251

Rajlich P, Synek J, Šarbach M, Schulmann K (1986) Hercynian-thrust related shear zones and deformation of the Varied Group on the contact of granulites (Southern Moldanubian, Bohemian Massif). Geol Rundsch 75: 665-683

Rapp RP, Watson EB, Miller CF (1991) Partial melting of amphibolite/eclogite and the origin of Archean trondhjemites and tonalites. Precambr Res 51: 1-25

RenÉ M (2007) Amphibolites of the Moldanubian Varied Group in the Chýnov area. Zpr geol Výzk v Roce 2006, 136-138

Richard P, Shimizu N, Allègre CJ (1976) ${ }^{143} \mathrm{Nd} /{ }^{146} \mathrm{Nd}$, a natural tracer: an application to oceanic basalts. Earth Planet Sci Lett 31: 269-278

Schulmann K, Kröner A, Hegner E, Wendt I, Konopásek J, LEXA O, ŚTíPSKÁ P (2005) Chronological constraints on the pre-orogenic history, burial and exhumation of deepseated rocks along the eastern margin of the Variscan Orogen, Bohemian Massif, Czech Republic. Amer J Sci 305: 407-448

Schulmann K, Lexa O, Štípská P, Racek M, TajČmanová L, Konopásek J, Edel J B, Peschler A, Lehmann J (2008) Vertical extrusion and horizontal channel flow of orogenic lower crust: key exhumation mechanisms in large hot orogens? J Metamorph Geol 26: 273-297

Steiger RH, JäGer E (1977) Subcommission on Geochronology; convention on the use of decay constants in geo- and cosmochronology. Earth Planet Sci Lett 36: 359-362

Sun SS, McDonough WF (1989) Chemical and isotopic systematics of oceanic basalts: implications for mantle composition and processes. In: Saunders AD, Norry M (eds) Magmatism in Ocean Basins. Geol Soc London Spec Pub 42: pp 313-345

Sun SS, Bailey DK, Tarney J, Dunham K (1980) Lead isotopic study of young volcanic rocks from mid-ocean ridges, ocean islands and island arcs. Philos Trans R Soc London A297: 409-445

ŠICHTÁR̆OVÁ I (1981) Moldanubian amphibolites in the area SE of Náměšt’ nad Oslavou. Věst Ústř úst geol 56: 203-214 
TAYlor SR, McLennan SM (1995) The geochemical evolution of the continental crust. Reviews in Geophysics 33: $241-265$

Veizer J, Ala D, Azmy K, Bruckschen P, Buhl D, Bruhn F, Carden Gaf, Diener A, Ebneth S, Godderis Y, Jasper T, Korte C, Pawellek F, Podlaha OG, Strauss H (1999) ${ }^{87} \mathrm{Sr} /{ }^{86} \mathrm{Sr}, \delta^{13} \mathrm{C}$ and $\delta^{18} \mathrm{O}$ evolution of Phanerozoic seawater. Chem Geol 161: 59-88

VoKurKa K (1995) Setting-up the method Sm-Nd in the Czech Geological Survey. Zpr geol Výzk v Roce 1993, 97-98

VRÁNA S (1992) The Moldanubian zone in Southern Bohemia: polyphase evolution of imbricated crustal and upper mantle segments. In: Kukal Z (ed) Proceedings of the $1^{\text {st }}$ International Conference on the Bohemian Massif. Czech Geological Survey, Prague, pp 331-336

VRÁNA S, ŠrámeK J (1999) Geological interpretation of detailed gravity survey of the granulite complex in southern Bohemia and its structure. Věst Čes geol úst 74: $261-277$

WendT I (1989) U-Pb Zirkondatierung und Sm-Nd Systematik sowie Petrologie und Geochemie an Granuliten und Gneisen aus dem Moldanubikum Südböhmens (ČSSR). Diplomarbeit, Institut für Geowissenschaften, Universität Mainz.

Wendt JI, Kröner A, Fiala J, TOdT W (1993) Evidence from zircon dating for existence of approximately 2.1 Ga old crystalline basement in southern Bohemia, Czech Republic. Geol Rundsch 82: 42-50

Wendt JI, KRÖNER A, Fiala J, TodT W (1994) U-Pb zircon and Sm-Nd dating of Moldanubian HP/HT granulites from south Bohemia, Czech Republic. J Geol Soc, London 151: 83-90

WiLson M (1989) Igneous Petrogenesis. Unwin Hyman, London, p. 1-466

WinCHESTER JA, Floyd PA (1976) Geochemical magma type discrimination; application to altered and metamorphosed basic igneous rocks. Earth Planet Sci Lett 28: 459-469

Winchester JA, Floyd PA (1977) Geochemical discrimination of different magma series and their differentiation products using immobile elements. Chem Geol 20: 325-343

Winchester JA, Park RG, Holland JG (1980) The geochemistry of Lewisian semipelite schists from the Gairloch District, Wester Ross. Scott J Geol 16: 165-179

Winchester JA, Floyd PA, Awdankiewicz M, Piasecki MAJ, Awdankiewicz H, Gunia P, Gliwicz T (1998) Geochemistry and tectonic significance of metabasic suites in the Góry Sowie Block, SW Poland. J Geol Soc, London 155: 155-164

Wolf MB, Wyllie PJ (1994) Dehydratation-melting of amphibolite at $10 \mathrm{kbar}$ : the effects of temperature and time. Contrib Mineral Petrol 115: 369-383

Wood DA (1980) The application of a Th-Hf-Ta diagram to problems of tectonomagmatic classification and to establishing the nature of crustal contamination of basaltic lavas of the British Tertiary volcanic province. Earth Planet Sci Lett 50: 11-30

Wood DA, Joron JL, Treuil M (1979) A re-appraisal of the use of trace elements to classify and discriminate between magma series erupted in different tectonic settings. Earth Planet Sci Lett 45: 326-336 